Boletín de la Sociedad Geológica Mexicana

VOLUMEN 60, NÚM. 1, 2008, P. 43-69

\title{
Geologic structure of the northern margin of the Chihuahua trough: Evidence for controlled deformation during Laramide Orogeny
}

\author{
Dana Carciumaru ${ }^{1, *}$, Roberto Ortega ${ }^{2}$ \\ ${ }^{1}$ Orbis Consultores en Geología y Geofísica, Mexico, D.F, Mexico. \\ ${ }^{2}$ Centro de Investigación Científica y de Educación Superior de Ensenada (CICESE) Unidad La Paz, \\ Miraflores 334, Fracc.Bella Vista, La Paz, BCS, 23050, Mexico. \\ *danadierna@gmail.com
}

\begin{abstract}
In this article we studied the northern part of the Laramide foreland of the Chihuahua Trough. The purpose of this work is twofold; first we studied whether the deformation involves or not the basement along crustal faults (thin- or thick- skinned deformation), and second, we studied the nature of the principal shortening directions in the Chihuahua Trough. In this region, style of deformation changes from motion on moderate to low angle thrust and reverse faults within the interior of the basin to basement involved reverse faulting on the adjacent platform. Shortening directions estimated from the geometry of folds and faults and inversion of fault slip data indicate that both basement involved structures and faults within the basin record a similar Laramide deformation style. Map scale relationships indicate that motion on high angle basement involved thrusts post dates low angle thrusting. This is consistent with the two sets of faults forming during a single progressive deformation with in - sequence - thrusting migrating out of the basin onto the platform.

We found that the style of deformation in the Chihuahua trough is variable. In places such as the East Potrillo Mountains and Indio Mountains is typical of the thin- skinned style, associated with the Cordilleran thrust belt, while in other places, the thick - skinned deformation present is typical of the Laramide orogeny in the southern Rocky Mountains. The Franklin Mountains record the transition from thick- to thin - skinned deformation. We notice that this difference in the style of deformation is related to the thickness of the Cretaceous section within the Chihuahua trough. On the other hand, the orientation of the shortening direction can be explained based on the geometry of the trough and especially the strike of its eastern margin. Along strike variations in shortening direction and kinematics are controlled by the curved northeast margin of the trough and reflect stress reorientation along the weak interface between the strong platform and weak basin interior. These processes were wide spread affecting the $300 \mathrm{~km}$ long eastern margin of the Chihuahua trough between El Paso and the Big Bend region of west Texas.
\end{abstract}

Key words: Chihuahua trough, kinematic analysis, Laramide orogeny, thin-skinned deformation, thick-skinned deformation, stress inversion.

\section{Resumen}

En este artículo estudiamos la parte norte del frente de arco de la Cuenca de Chihuahua. Éste trabajo tiene dos objetivos: el primero es estudiar si la deformación involucra o no el basamento a lo largo de fallas en la corteza (deformación de piel delgada o gruesa) y el segundo es estudiar la naturaleza de las direcciones de acortamiento en la cuenca de Chihuahua. En esta región los estilos de deformación de fallamiento inverso cambian de moderado a bajo ángulo dentro de la cuenca, incluyendo el fallamiento inverso en la plataforma adyacente. Las direcciones de acortamiento estimadas de los pliegues y fallas, y la inversión de estrias de fallas indican que las estructuras de la cuenca y del basamento registran similar estilo de deformación a las deformaciones de las estructuras Laramide. Las relaciones que se observan a escala cartográfica indican que el movimiento de alto ángulo en el basamento incluyen 
fallas inversas posteriores de bajo ángulo. Este estilo es consistente con las dos series de fallas que se formaron en una deformación progresiva migrando de la cuenca a la plataforma. En este trabajo encontramos que el estilo de deformación de la cuenca de Chihuahua es variable. En regiones como East Potrillo Mountains y las Indio Mountains es típica la deformación estilo 'piel delgada', mientras que en el sur de las Rocky Mountains el estilo es de 'piel gruesa'. Las Franklin Mountains registran transición de delgada a gruesa. Por otro lado la dirección de acortamiento se puede explicar basada en la geometría de la cuenca, especialmente en el margen occidental. A lo largo de la cuenca, las variaciones de acortamiento y la cinemática del movimiento de las fallas están controladas por la curvatura del margen noroccidental y reflejan la reorientación de esfuerzos sobre una débil interface entre la plataforma y el interior de la cuenca. Éste proceso se extiende a lo largo de los $300 \mathrm{~km}$ que cubre el margen occidental de la cuenca de Chihuahua entre El Paso y la región de Big Bend en el oeste de Texas.

Palabras clave: Orogenia Laramide, Norte de Mexico, Cuenca de Chihuahua.

\section{Introduction}

The Chihuahua trough is a major sedimentary basin of Mesozoic age located in the southern part of the North American craton that lies along the U.S.A - Mexico border (Figure 1). Laramide crustal shortening strongly deformed the basin. This basin was intensely deformed by contractional structures associated with the Laramide orogeny and extensional structures related to the Rio Grande rift. This paper focuses on Laramide structures. In general, the Laramide foreland is composed of a relatively thin marine sedimentary wedge where the thrust system flattens into a subhorizontal detachment separating the deformed rocks from the basement below, namely thin - skinned deformation. However in southern New Mexico, west Texas and northern Chihuahua, the style of deformation is usually thick-skinned. The nature of this thick - skinned style of deformation has been under debate for many years. This debate has centered on whether the main style of deformation is the thin- or thick - skinned model.

Only a few descriptive models (Haenggi, 2001) have been presented to explain the tectonic evolution of the trough. In order to investigate the basin, we reconstructed the tectonic history by means of dynamic, kinematic and geometric analysis. This study is based on structural geology of the faults and folds, detailed mapping of East Potrillo, Franklin Mountains and Cerro de Cristo Rey and compilation of the large amount of geological data now available for this region (Brown and Clemons, 1983; Cather, 2001; Corbitt and Woodward, 1973; Drewes and Dyer, 1993; Harbour, 1972; Kelley and Matheny, 1983; Lovejoy, 1976 and 1980; Seager, 1975; Seager and Mack, 1994; Rohrbaugh, 2001; Wu, 2002, Zeller, 1970).

One of the striking features of the Chihuahua trough and much of the Laramide foreland in New Mexico and Colorado is that deposition of marine clastic successions continued until Maastrichtian time (Jones et al., 1998; Seager and Mack, 1985) just prior to the onset of Laramide shortening. Thus, much of the Laramide foreland is composed of a relatively thin marine sedimentary wedge (Coney, 1978; Jones et al., 1998). The Chihuahua trough is one of the thickest sections of lower Cretaceous rocks within the Laramide foreland and greatly influenced the style of deformation in southern New Mexico, west Texas and northwestern Chihuahua (Seager and Mack, 1985). We show that the variation in structural style between basement involved faulting in southern and southwestern New Mexico and thin skinned thrusting within the Chihuahua trough is caused by changes in thickness of the Mesozoic cover thus helping to explain contrasting views of this part of the Laramide orogen (Corbitt and Woodward, 1973; Drewes, 1982; Seager and Mack, 1985).

\section{Geological Setting}

The Laramide orogen of western North America is a chain of generally north trending block uplifts stretching from Montana to Mexico (Coney, 1972). These uplifts are generally cored by Precambrian rocks and commonly have high angle reverse faults on one or both margins of the uplifts which root into subhorizontal detachments at depth (Erslev and Rogers, 1993). Laramide deformation is generally bracketed to have occurred between the late Cretaceous ( $\sim 85 \mathrm{Ma})$ and the Eocene ( 36 Ma) (Bird, 1998). The earliest Laramide deformation overlaps in time with the end of thrusting within the Cordilleran orogenic belt (Bird, 1988). Several models have been proposed to drive Laramide orogenesis including, low angle subduction (Bird, 1988; Dickinson and Snyder, 1978), detachment and delamination within the crust (Erslev, 1993; Oldow et al., 1990), collisional orogenesis (Maxson and Tikoff, 1996), extension within the Sevier hinterland (Livaccari, 1991), rotation of the Colorado Plateau (Cather, 1999) and lithospheric buckling (Tikoff and Maxson, 2001). All of these mechanisms attempt to explain the transmission of stress well into the plate interior causing deformation of the foreland.

The kinematics of the Laramide orogeny has been controversial. For instance many models for Laramide orogenesis emphasize contractional strains with little to no transcurrent component (Hamilton, 1988; Woodward et al., 1997). In contrast, other models have emphasized the importance of right handed transcurrent displacement during Laramide 


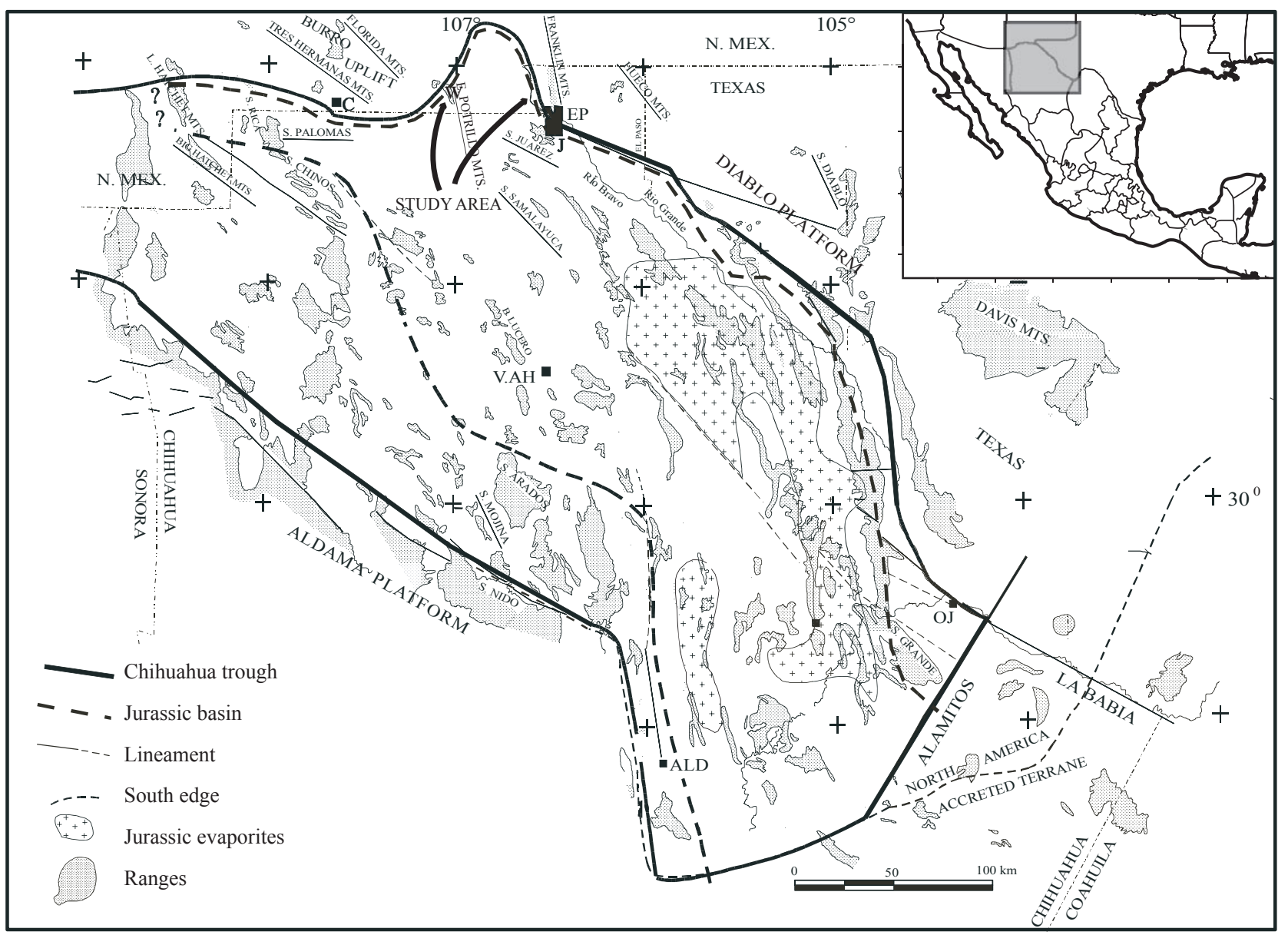

Figure 1. Geological features of the Chihuahua trough. The current boundaries are the Aldama platform and Alamitos lineament at the south and the Diablo Platform at the north. Villa Ahumada (V.AH), Ojinaga (OJ), Aldama (ALD), Van Horn (VH and El Paso (EP) are indicated (after Haenggi, 2001).

orogenesis in Colorado and New Mexico along the eastern edge of the Colorado Plateau (Cather, 1999; Chapin and Cather, 1981; Karlstrom and Daniel, 1993). A key part of resolving this controversy is deciphering the kinematic history of Laramide fault zones (Erslev, 2001) and understanding how strain is transferred to the north and south of the proposed region of transcurrent displacement.

Within the study area, in northern Chihuahua, southern New Mexico and west Texas, the Cordilleran orogen and the Laramide orogen overlap. Corbitt and Woodward (1973) and Drewes (1988) concluded that although the structures in this region were roughly contemporaneous with those in the Laramide Rockies, they had a distinct deformation style and represented the southern continuation of the Cordilleran fold and thrust belt. In contrast, Seager and Mack (1985) concluded that uplifts and basins in this region were structurally similar to those in classic Laramide ranges. They further concluded that differences in deformation style were attributed to deformation within thick sequences of Mesozoic strata and locally developed transpressive structures.

In this work we used the definition of Chihuahua Trough proposed by Gries (1970), which describes it as a Jura - Cretaceous basin with several thousand meters of marine and siliciclastic rocks built on a base of Jurassic evaporates. DeFord (1964) first used the term "Chihuahua trough" to name the depositional basin that contained the thick Mesozoic sediments and are exposed today in the Laramide Chihuahua tectonic belt. The extent of the Chihuahua trough as defined by DeFord was northeastern Chihuahua and adjacent parts of Texas, New Mexico and Sonora that form a deep Mesozoic basin. An arbitrary southern boundary (Figure 1) is placed at the edge of the North American Craton (Marathon fold and thrust belt). Muehlberger (1980) selected two arbitrary limits: a northwestern limit is selected along the $109^{\circ} \mathrm{W}$ meridian and a southeastern limit is along the Alamitos lineament. The basin extends beyond these boundaries to the south into Coahuila and to the west into Arizona and Sonora. In its present configuration, the Chihuahua trough is a NW - SE elongated elliptical basin bounded by the Aldama Platform to the southwest and by the Diablo Platform to the northeast. The late Paleozoic Pedregosa basin is, in effect, the proto - Chihuahua trough (Haenggi, 2001). 
The Chihuahua trough was subsequently shortened in Laramide time leading to intense folding and imbrication of the Jura - Cretaceous section. (Gries, 1970; Seager and Mack, 1985). Jurassic evaporates at the base of the section formed a décollement during Laramide shortening (Gries, 1970). The fold and thrust belt built within the Chihuahua trough is referred to as the Chihuahua tectonic belt and trends parallel the trough's northeast margin. Its northeast margin of the trough is defined by an abrupt transition from the thick Mesozoic section onto the Diablo Platform dominated by Permian sedimentary rocks rest- ing unconformably on Precambrian basement (Figure 2 and 3). Cretaceous rocks only form a thin veneer covering Permian rocks on the southeast margin of the Diablo Platform (Figure 3 and 4).

Triassic and Jurassic rocks generally are absent over most of southern New Mexico, although marine Jurassic rocks are known from a deep oil test southwest of Las Cruces (Seager and Mack, 1985). These Jurassic carbonates thicken southward into the Chihuahua trough where Jurassic evaporites are diapiric and are responsible for Laramide décollement and thin-skinned folding in the

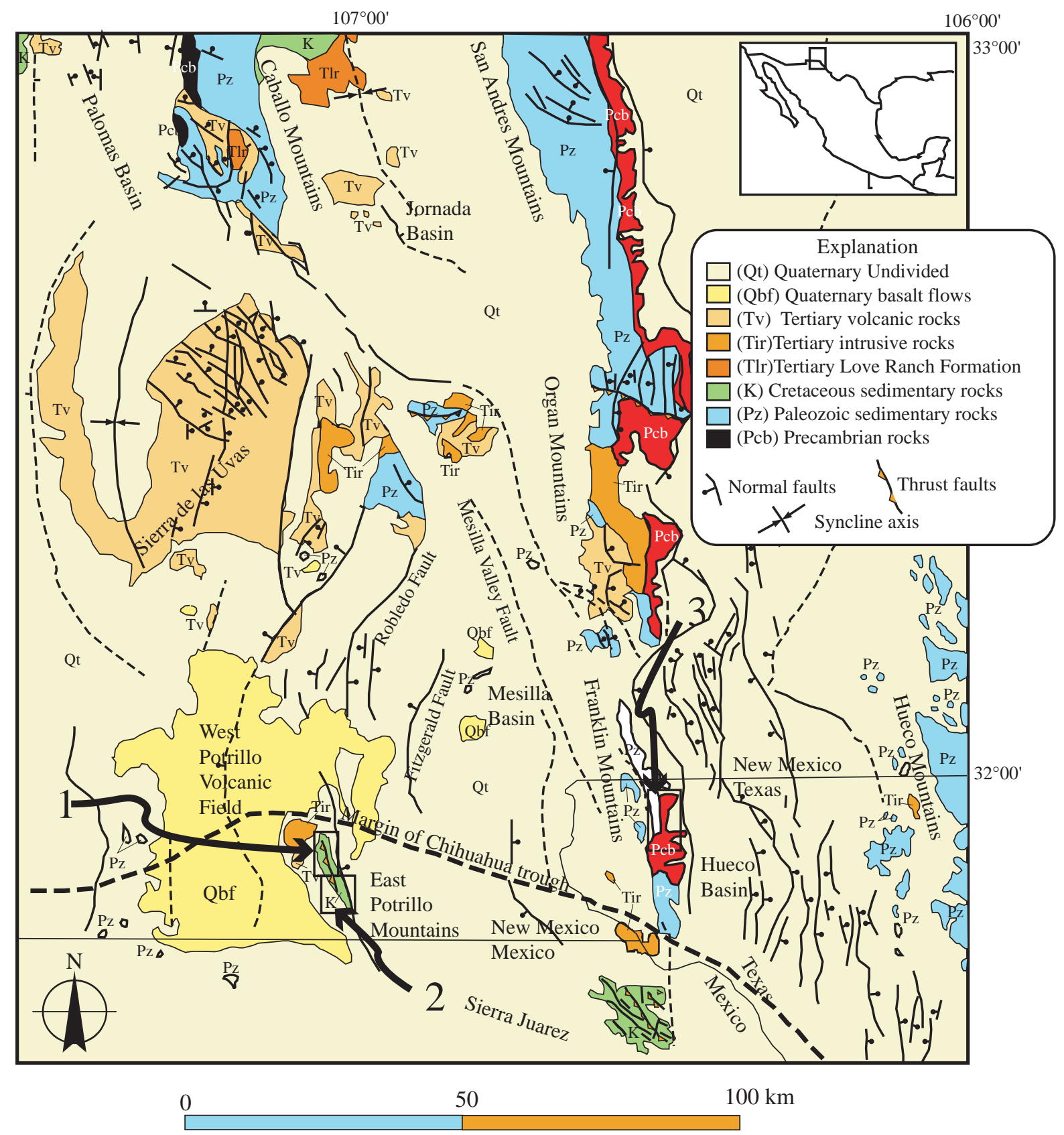

Figure 2. Geological features of southeast New Mexico and adjacent regions. The major faults and geological units are indicated. The two important ranges in the southern Mesilla basin are the East Potrillo Mountains (insets 1 and 2) and Franklin Mountains (inset 3) (modified after Ruiz, 2004). 


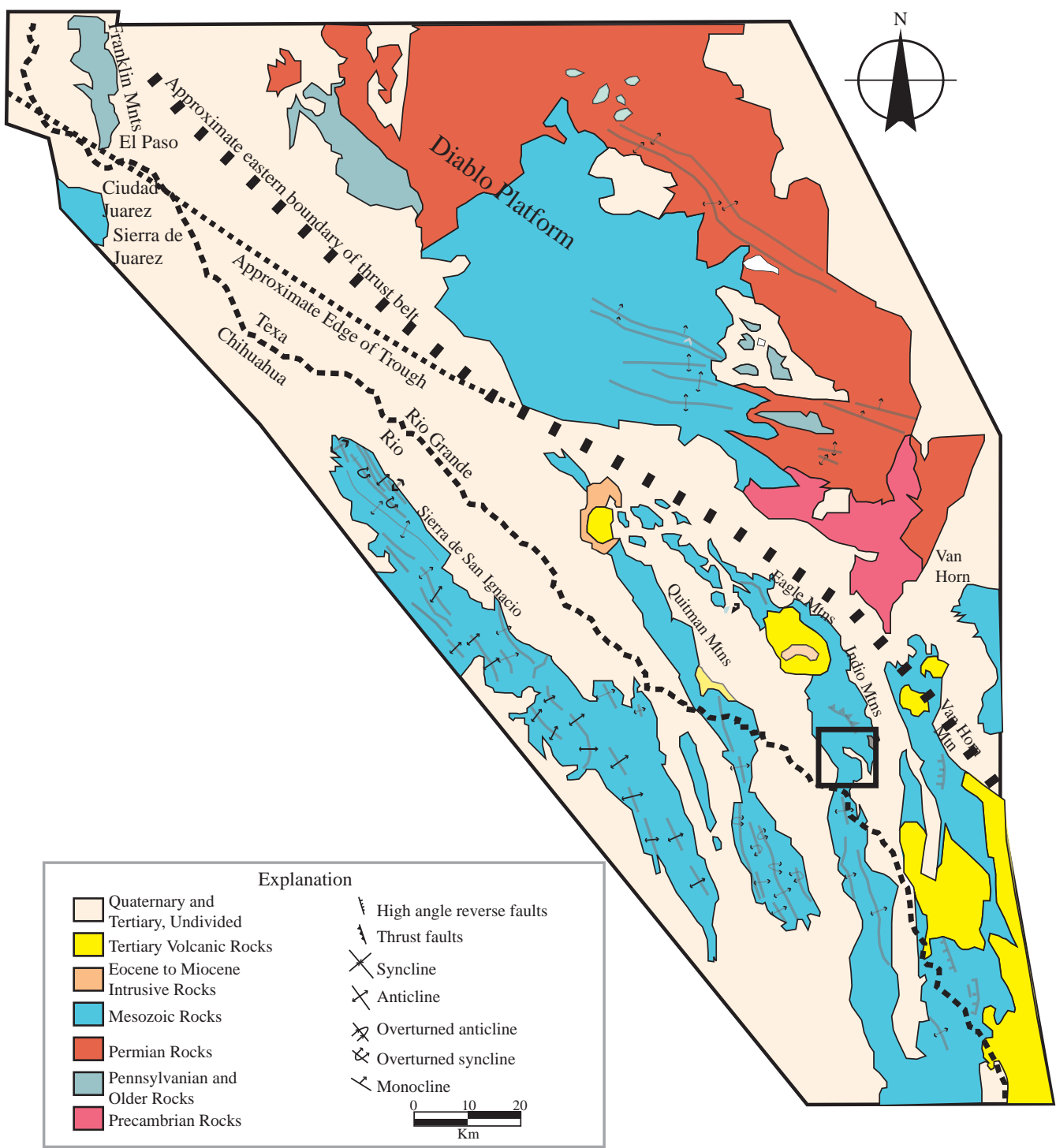

Figure 3. Tectonic map of northeastern margin of the Chihuahua trough southeast of El Paso, Texas showing location of the Indio Mountains (see box). Note position of trough margin with respect to edge of fold and thrust belt (modified after Rohrbaugh, 2001).

Chihuahua tectonic belt, including the Sierra de Juarez (Drewes and Dyer, 1993; Gries and Haenggi, 1970; Gries, 1970; Seager and Mack, 1994). The age of these evaporites are controversial, Haenggi (2002) proposed that these evaporites are deposited above a basal Jurassic clastic section, therefore, they belong to a post-Jurassic deposition (probably Neocomian). Cretaceous strata thin dramatically across the study area, from the interior of the trough onto the Diablo Platform. For instance, in the Indio Mountains along the Texas - Mexico border Reaser (1982) reports a thickness of $5652 \mathrm{~m}$ for Cretaceous rocks in a deep oil test. Immediately to the east Underwood (1962) reports a thickness of $1549 \mathrm{~m}$ in measured sections of the Cretaceous. Similarly, in the El Paso area the thickest section of Cretaceous rocks is found in the Sierra de Juarez where exposed Cretaceous rocks have a thickness of $1388 \mathrm{~m}$ (Seager and Mack, 1994). Going northwest towards the basin margin at Cerro de Cristo Rey Cretaceous rocks have an exposed (minimum) thickness of $495 \mathrm{~m}$ (Lovejoy, 1976). Farther to the northeast, in the foothills of the Franklin Mountains the Cretaceous section is less than $100 \mathrm{~m}$ thick (Lovejoy, 1975).

This dramatic thinning of section on northeastern margin of the trough is controlled by a series of large displacement, down to the west, normal faults of Jurassic age (Uphoff, 1978). The margin roughly parallels the Rio Grande and encroaches up to $25 \mathrm{~km}$ onto the Texas side of the border, from El Paso to the southwestern edge of Big Bend National Park (Figure 1). Muehlberger (1980) also postulated a reentrant into the eastern part of the Big Bend area because Laramide structures are similar to those along the margin of the trough. The normal faults were subsequently 


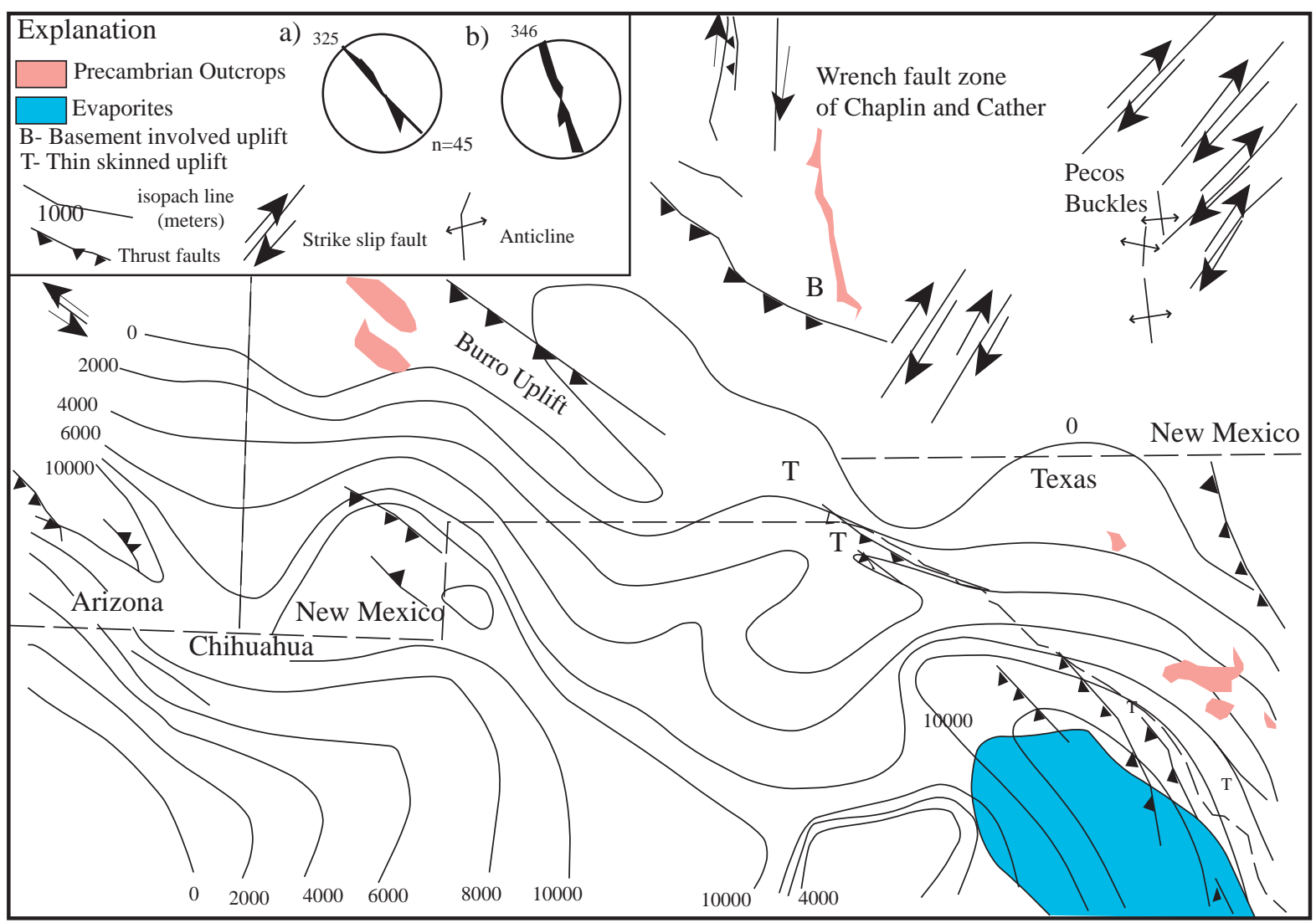

Figure 4. Isopach map for the base of the lower Cretaceous rocks ( Neocomian - Aptian) in and around the Chihuahua trough, after LeMone et al., (1983). Faults are adapted from Seager and Mack, (1985). a) Rose diagram showing trends of folds shown in figure 2.3 north of line marked "Rose Line". b) Rose diagram showing trends of folds shown in Figure 2.3 south of line marked "Rose Line". See text for discussion.

buried by a thick Cretaceous sequence, but Uphoff (1978) interpreted well data to show the existence of one of these faults beneath the Hueco Bolson and Mack (2004) also describes one from the Bisbee group in southeast Arizona. These normal faults are important because they determine the geometry of the sedimentary basin and helped control the location of Laramide structures.

\section{Methods}

In order to determine the kinematic and strain history of the Chihuahua trough during Laramide deformation geometric data on the orientations of faults, folds, and fractures were collected in the field. Locations of data observations ( $\sim 10 \mathrm{~m}$ accuracy) were obtained using handheld GPS units. For the paleostress analysis fault orientation and slip direction were inverted for the orientations of the three principal stresses (Angelier, 1984). These analyses were performed in the East Potrillo Mountains, Cerro de Cristo Rey, and the northern Franklin Mountains. This data is compared with preexisiting data sets from the southern Franklin Mountains and Indio Mountains. The dataset in these areas was split into domains based on structural ge- ometries. Principal Laramide structural geometries will be described and interpreted in the following sections.

In order to estimate the regional shortening direction, bedding plane orientations were measured in order to obtain fold axes. Assuming a cylindrical geometry of the folds, a best fit circle can be fit to the poles to bedding planes, and the pole to this great circle represents the fold axis (Ramsay and Huber, 1983). In most cases the shortening direction is taken to be perpendicular to the fold axis. Slaty cleavage was also used in order to better constrain the shortening direction. Poles to cleavage generally approximate the local shortening direction (Ramsay and Huber, 1983). For faults, the orientation of slickensides were measured and assumed to represent the direction of maximum shear stress in the fault plane. Shear sense in brittle faults was inferred from the geometry of calcite veins adjacent to faults, steps in slickensides on the fault planes, geometry of Reidel shears and conjugate fault sets (Petite, 1987). Calcite and quartz filled vein arrays were also measured and used to infer the orientation of the least compression direction.

Paleostress reconstruction is based on fault slip inversion. The inverse method assumes that faults slip in the direction of shear stress acting on the fault plane. Suppose that 
we have $\mathrm{N}$ measurements and all the faults slipped under the stress $\boldsymbol{\sigma}$. The shear traction at the $\alpha$ th fault, $\mathbf{s}^{\alpha}$, is defined as:

$$
\mathbf{s}^{\alpha}=\sigma \mathbf{n}^{\alpha}-\left[\left(\mathbf{n}^{\alpha}\right)^{T} \sigma \mathbf{n}^{\alpha}\right] \mathbf{n}^{\alpha}
$$

where $\mathbf{n}^{\alpha}$ is the unit vector normal to the $\alpha$ th fault, and $T$ means the transpose of the matrix. The slip direction measured at the field is expected to be in the direction $-\mathbf{s}^{\alpha}$. The stress tensor is determined by minimizing the sum of the angular misfits of $\mathbf{s}^{\alpha}$. Basic assumptions behind all stress inversions are that each fault is caused by a homogeneous stress field, the fault has not been reoriented, and that the slip direction in the fault represents the direction of maximum resolved shear stress (Ramsay and Lisle, 1997). Since only angles are measured, we obtain only the orientations of the three principal stresses and the ratio of the three principal stress differences $\varphi$. Three methods were used for stress inversion in all the different areas, in all the cases the number of data was greater than 30 , however in some cases we divided the studied area in subregions. The first method is the moment tensor summation as coded by Allmendinger (2001). The second is the inverse method of Michael (1984) which allows the use of fold measurements. The third is the inversion method of Marrett and Allmendinger (1991). The results are obtained in terms of a 1) reduced stress tensor, consisting of the components of the principal stresses and 2) the ratio of principal stress differences. The stereoplots were constructed using Stereowin, a Stereonet program for Windows ( Allmendinger, 2002 - 2003).

\section{Results}

The region studied in this work is depicted in Figures 2 and 3 indicating the ranges around the Rio Grande rift. In the following sections we discuss the five regions studied: East Potrillo Mountains, Franklin Mountains, Anthony Gap and Tom Mays Park, Cerro de Cristo Rey and Indio Mountains.

\subsection{East Potrillo Mountains}

The East Potrillo Mountains are located 20 - 22 miles south of Las Cruces, New Mexico and are part of a north - northwest trending mountain chain that crosses the New Mexico - Mexico border (Figure 1,5 and 6). They form an isolated outcrop of Permian and Cretaceous rocks along the northern margin of the Chihuahua trough. In the East Potrillo Mountains, Seager and Mack (1994) measured 1,900 ft of marine clastic and carbonate shelf deposits above a basal conglomerate, all of which thin southward along the range. These somewhat arkosic clastics and limestone contain an Albian - Aptian fauna and correlate with the Hell-toFinish and U-Bar formations of southwestern New Mexico (Seager and Mack, 1994). Conglomerate beds contain clasts of early Cretaceous carbonates (Broderick, 1984) and are therefore younger than early Cretaceous.

Thrust faults and folds are well exposed in the East Potrillo Mountains (Figure 5, 6 and 7). These contractional structures are the major deformation features in the East Potrillo Mountains. Most of the studied thrust faults are located in the northern part of the range. They are parallel to the general alignment of the range with faults dip $30^{\circ}-60^{\circ}$ towards the southwest. Slickensides on fault surfaces and the strongly asymmetric nature of fault related folds indicate that the hanging walls of the major faults moved towards the northeast relative to the footwalls.

The strongly asymmetric nature of the folds (Figure 7) and presence of thrust faults cutting up through the overturned limbs of the folds is consistent with the folds being the result of fault propagation, similar to examples cited by Erslev and Rogers (1993). Fault propagation folds form at the tip of a growing fault as fault displacement increases. This is because the shortening strain taken up by the fault is absorbed by folding at the tip of the fault. A consequence of this process is that the folds tighten as the fault propagates until folding becomes inefficient and a fault breaks thorough the limb of the fold. Fault propagation folding produces a triangular shear zone that widens away from the fault tip, with the highest strain being near the fault tip and strain decreasing away from the fault tip (Suppe and Medwedeff, 1990). Strain within the triangular shear zone at the fault tip can be accumulated by flexural slip folding, cataclastic flow, rigid body rotation, and plastic flow of incompetent materials. To evaluate the roles of these mechanisms, the folds and associated faults were carefully studied. On the other hand, there is a problem in directly relating the inferred stresses to folding since the stresses at any stage of the deformation may have no simple geometrical relationship to the folding process. Parallelism of principal stresses and strains relationship may hold true for coaxial deformation, but would not hold true if the bulk deformation is significantly non-coaxial. In anyway, folding analysis was performed only for completeness.

In most cases, bedding is generally well preserved with obvious primary sedimentary structures. This generally rules out pervasive cataclastic or plastic flow as being the dominant folding mechanisms, with an important exception discussed below. Bedding planes in sandstones and limestones are frequently marked by slickensides, suggestive of flexural slip. Plots of poles to bedding show that fold axis plunge $2^{\circ}$ to $350^{\circ}$ (Figure 8 ).

Plots of poles to thrust fault planes are shown in Figure 8. As can be seen, most faults dip toward the southwest at moderate angles, however a large number of faults dip northeast. Field observations show that these faults generally occur parallel to or at low angles to northeast dipping bedding planes. Fitting a great circle to poles to fault planes yields a beta axis of $6^{\circ}$ to $337^{\circ}$, essentially parallel to the fold axis determined from the bedding planes.

This close geometric relationship shows that faulting and 


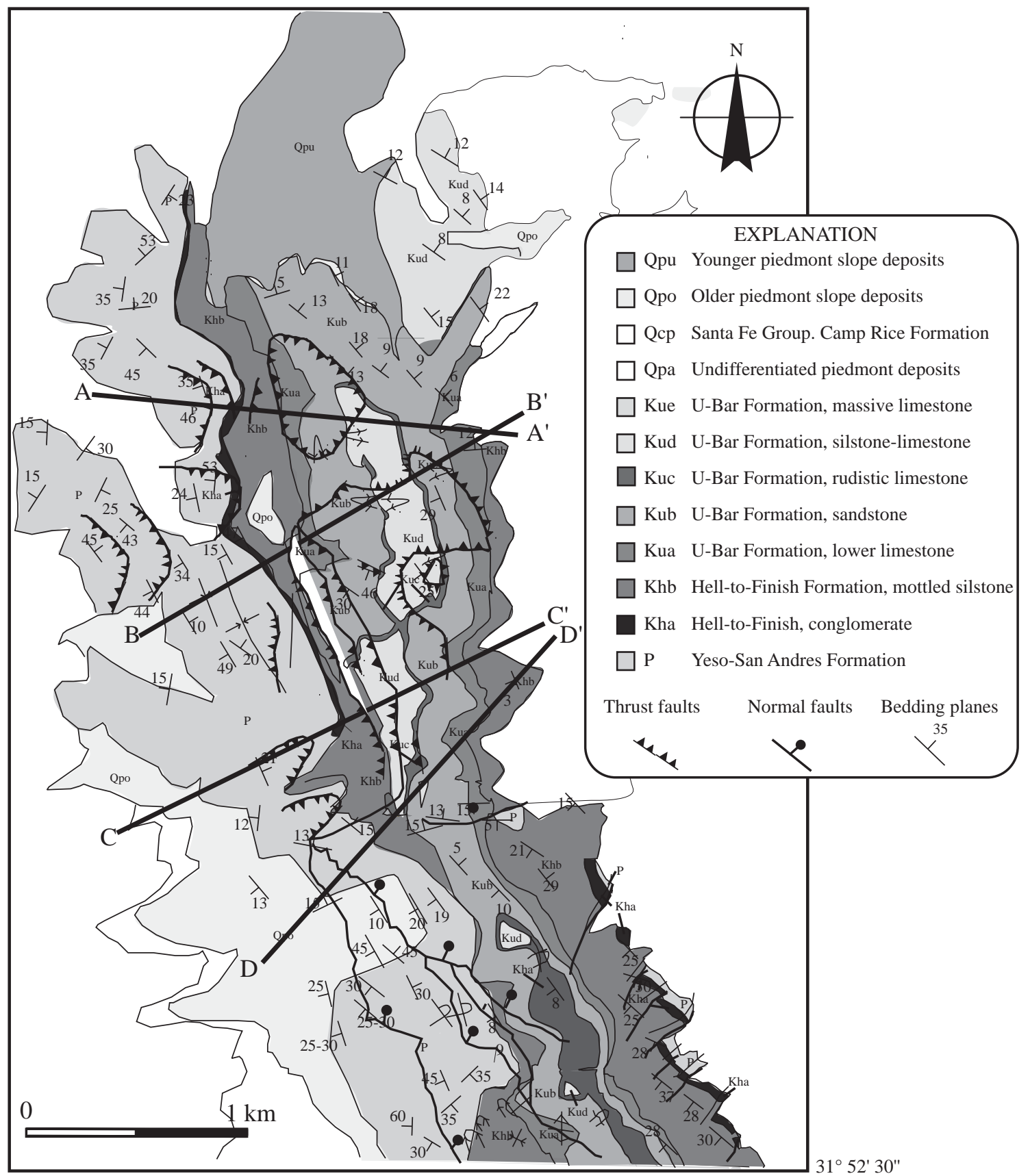

Figure 5. Geologic map of the northern part of the East Potrillo Mountains from Seager and Mack (1994) and field reconnaissance.

folding are cylindrical with respect to each other. To summarize, cataclastic flow and pervasive plastic flow are unlikely to have been important deformation mechanisms in sandstone, conglomerate and limestone during folding in the East Potrillo Mountains. Presence of slickensides on fault planes combined with the close geometric relationships between the faults and folds shows that flexural slip was the dominant folding mechanism in these lithologies. An important exception to the above is in the mottled siltstone member of the Hell-to- Finish formation. In the mottled siltstone member considerable evidence is present for the operation of pressure solution during folding. For instance, a tectonic cleavage defined by a millimeter scale parting is developed. In places the cleavage is as strong as or stronger than bedding. This cleavage is highly variable in its degree of development ranging from completely absent to being present as widely separated cleavage domains, to a pervasive pencil cleavage, to a fully developed slaty cleavage. It is difficult to assess what factors controlled the intensity of cleavage development, but in 
$107^{\circ} 00^{\prime}$

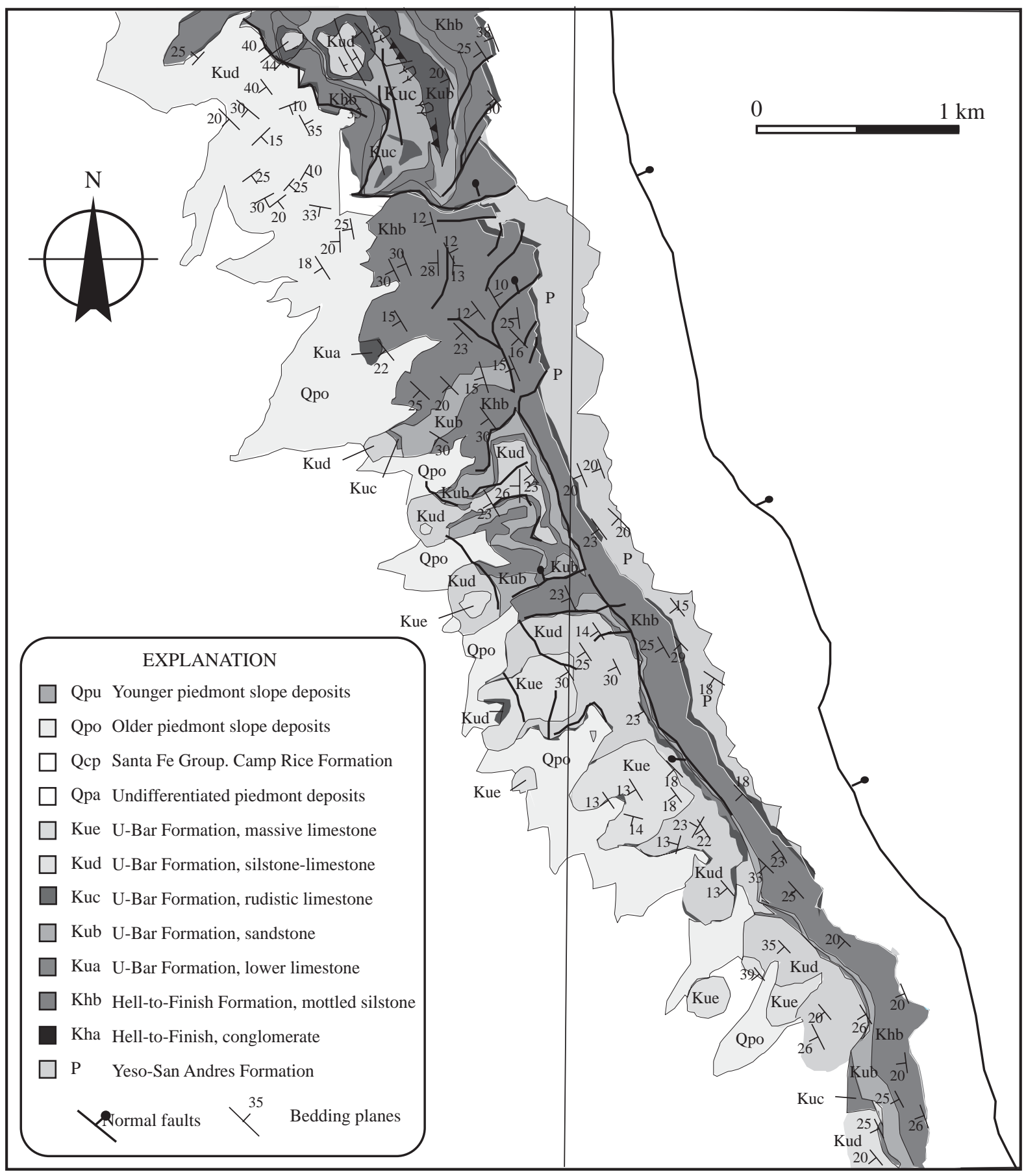

Figure 6. Geologic map of the southern part of the East Potrillo Mountains from Seager and Mack (1994) and field reconnaissance.

general the most intensely cleaved rocks are found on the overturned limbs of folds. Evidence for pressure solution during cleavage development comes from several observations. First, cleaved rocks are often associated with calcite and quartz vein networks. Second, many of the cleaved rocks contain millimeter or larger crystals of pyrite and are bleached white or light gray, suggesting reduction of hematite which forms cement in these rocks. Third is the development of pits on pebbles in thin conglomerate layers within the mottled siltstone. Taken together these observations suggest that pressure solution was the deformation mechanism associated with folding in the mottled siltstone. Further evidence for ductile strain within the mottled siltstone member is the development of boudinage where more competent sand beds are found interlayered with the siltstone (Figure 9). 


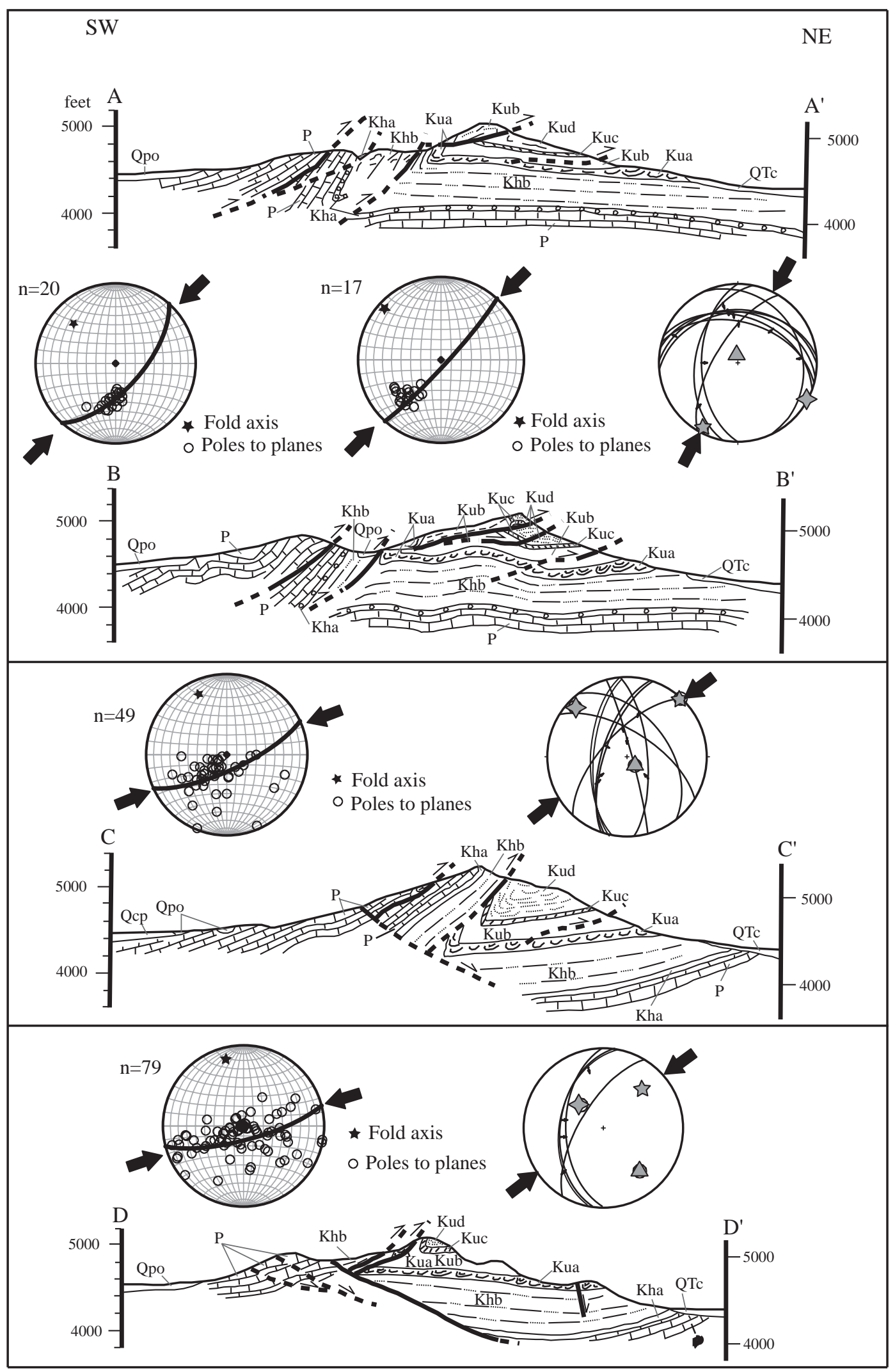

Figure 7. Cross sections in the East Potrillo Mountains (after Seager and Mack, 1994). The stereographic projections of poles to bedding and the fold axis were added for all the regions; the shortening direction is indicated. The stress inversion results are also presented; $\sigma_{1}, \sigma_{2}$ and $\sigma_{3}$ are the principal stress axis of the stress tensor $\left(\sigma_{1}>\sigma_{2}>\sigma_{3}\right)$ represented with five, four and three star points respectively. 
a)

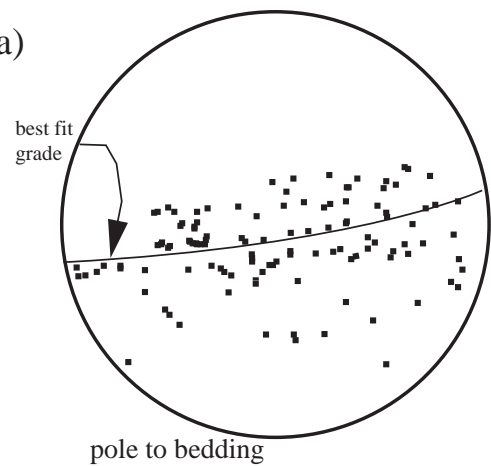

c)

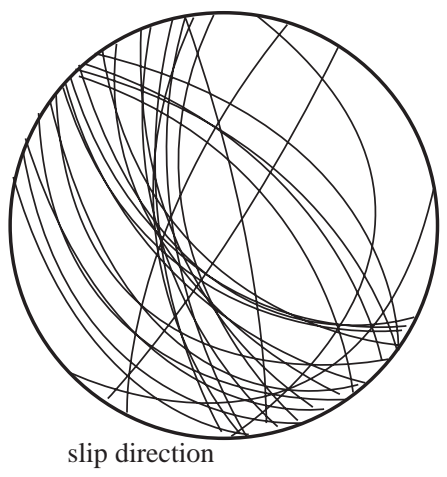

b)
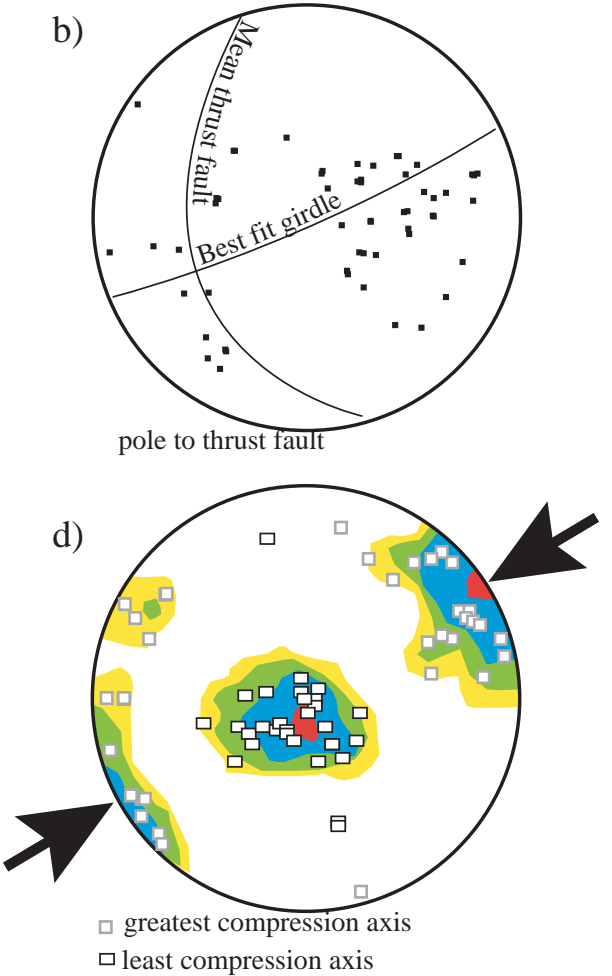

Figure 8. Stereonets of summarizing structural data in the northern Potrillo Mountains (area of figure 2.5). a) Poles to bedding with best fit great circle shown. Star indicates orientation of inferred fold axis. b) Poles to thrust faults. Star shows pole to best fit great circle. c) Faults plotted as great circles with slip direction inferred from slickensides shown. d) Greatest compression and least compression axes determined for faults in c) using the inversion method of Marrett and Allmendinger (1991). Contours for compression and tension axis are also shown. Data are consistent with northeast - southwest horizontal compression and vertical extension.

In order to evaluate if the pressure solution cleavage formed during folding or another phase of deformation, poles to cleavage were plotted on stereographic projection. A great circle fit to the poles to cleavage yields a beta axis of 11 to 343 , sub parallel to the fold axis calculated from poles bedding (Figure 10). This again suggests that the cleavage in the mottled siltstone member of the Hell-toFinish formation formed synchronously with fault propagation folding.

To evaluate the orientation of the stresses responsible for folding, fault slip inversion was performed. A total of 56 thrust faults were measured in the northern part of the East Potrillo Mountains (Figure 8). Of those 41 faults had slickensides which could be used to infer the slip direction and the sense of shear. Of these faults, 37 gave solutions for the orientations of the greatest compression axis and least compression axis which are shown in Figure 8 (d), using the method of Marret and Allmendinger (1991). Distribution of compression and tension axes is consistent with a thrust strain field of northeast - southwest horizontal compression and vertical extension (Figure 8, d). There is a larger variation in the inferred shortening direction than the inferred extension direction suggesting either superposed deformation, rotation of faults during progressive strain or a heterogeneous stress field. Of these possibilities, it is most likely some of the faults were reoriented during fault propagation folding. It is also possible that the stress field was heterogeneous at the scale of the study area. Field relationships however, show no evidence of large scale cross - cutting relationships making it likely that contractional deformation resulted form a single progressive deformation, not superposed deformation, consistent with the interpretations of Seager and Mack (1994).

To further evaluate the possibility of a heterogenous stress field and possible limitations of inversion method, stress inversion was also preformed on selected locations using the inversion method of Michael (1984) and the direct inversion method of Allemendinger (2001). Three locations were selected in the northern part of the East Potrillo Mountains and results are shown in Figure 11 and 12. As can be seen each of these regions gives stress orientations which are generally consistent with northeast - southwest shortening and subvertical extension. However the direct inversion method (Allmendinger, 2001) gives results which diverge the most from the other two inversion methods. However, the fault data when combined with the orientations of folds at all three localities (Figure 7) are consistent with northeast - southwest horizontal shortening across the region.

Intensity of deformation in the East Potrillo Mountains varies form north to south. In the southern part of the range a nearly complete stratigraphic section from the base of 


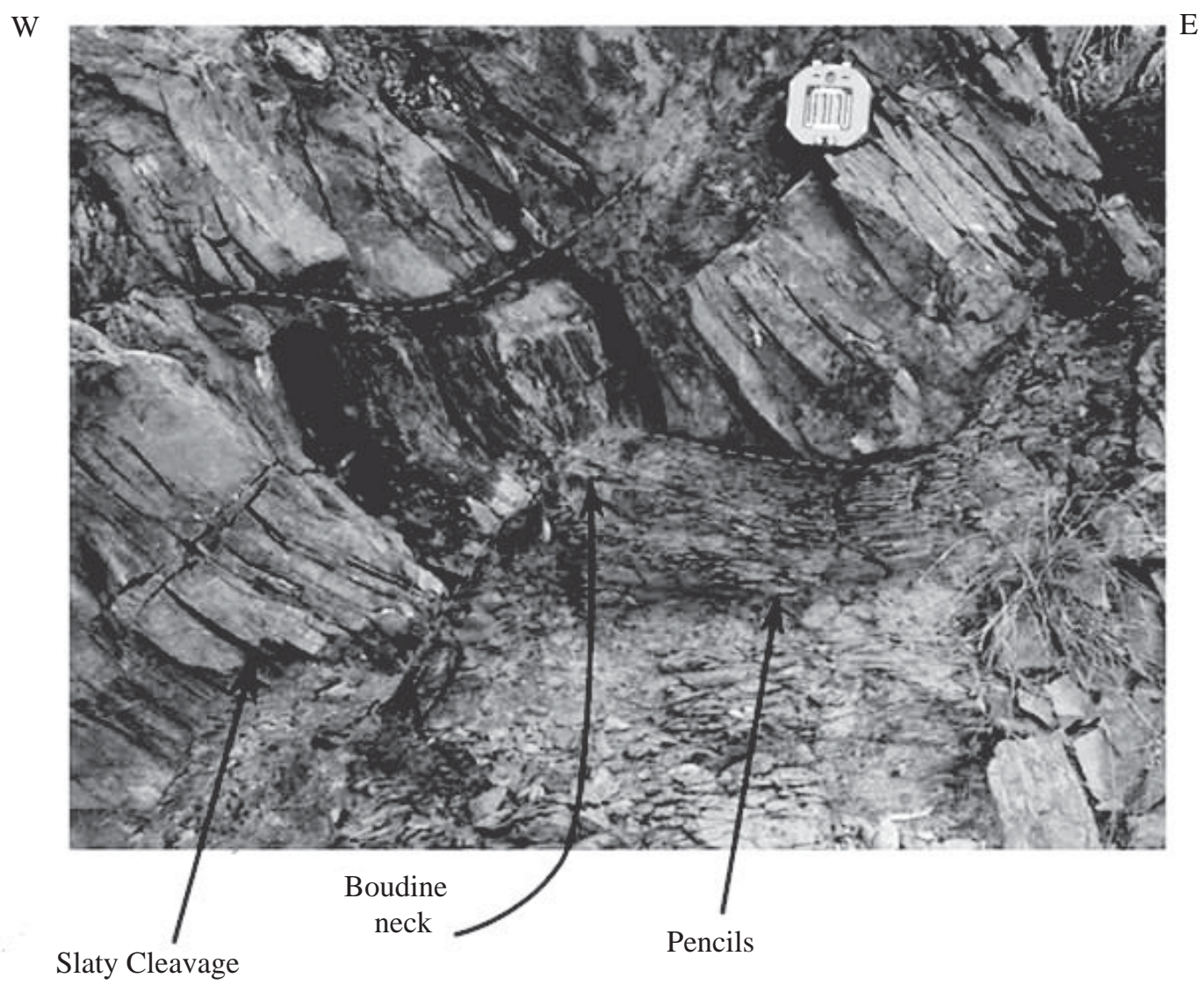

Figure 9. Boudine neck and slaty cleavage provide evidence for ductile deformation of the mottled siltstone in the East Potrillo Mountains. The cleavage is related to asymmetric folds developed during Laramide deformation.

the Cretaceous to the upper siltstone member of the U-bar formation is exposed and is uninterrupted by thrust faults (Figure 6). The first major thrust fault and associated folds occurs in the central part of the range in the hanging wall of a major (younger) low angle normal fault (Figure 5). North of the fault complexity and intensity of the contractional structures increase. Greatest shortening in the range occurs nears its northern end. In this area Permian rocks are thrust over the siltstone - limestone member of the U-Bar formation implying $\sim 427$ meters of stratigraphic repetition.

\subsection{Franklin Mountains}

The Franklin Mountains are a key exposure of the Chihuahua tectonic belt because they record the transition from thick - skinned basement involved thrusting (typical Laramide style) to the thin - skinned thrusting of the belts interior (Wu, 2002). The range is a west tilted fault block on the eastern margin of the Mesilla Basin and is composed of Paleozoic and Precambrian rocks which dip homoclinally towards the west at $\sim 30^{\circ}(\mathrm{Wu}, 2002)$. Laramide structures are best developed in rocks that are Pennsylvanian and younger found along the western side of the range. The youngest of these structures belong to Cretaceous rocks that are located along the west side of the range with the largest outcrop occurring at Cerro de Cristo Rey just to the southwest of the Franklin Mountains (Figure 2 and 13). An important feature of the range is the presence of the thin - skinned style thrusting in Pennsylvanian and younger rocks on the western side of the range. In contrast, high angle reverse faults and basement involved faults are restricted to the western boundary fault zone and stretch from the southern tip of the range to Tom Mays Park in the central Franklin Mountains (Lovejoy, 1975; Wu, 2002). Prior work in the Franklin Mountains identified Laramide structures as being a large syncline and anticline pair exposed southwest of Anthony Gap (Figure 13), a west trending monocline north of the Webb Gap and a southwest - trending monocline southeast of North Anthony's Nose (Kelley and Matheny, 1983). Because these folds have not been precisely dated their assignment to Laramide tectonism has been based on their similarity to Laramide structures regionally (Chapin and Seager, 1975).

\subsection{Anthony Gap and Tom Mays Park}

The area from Anthony Gap extending south, including low hills west of the range at Tom Mays Park, exposes a 

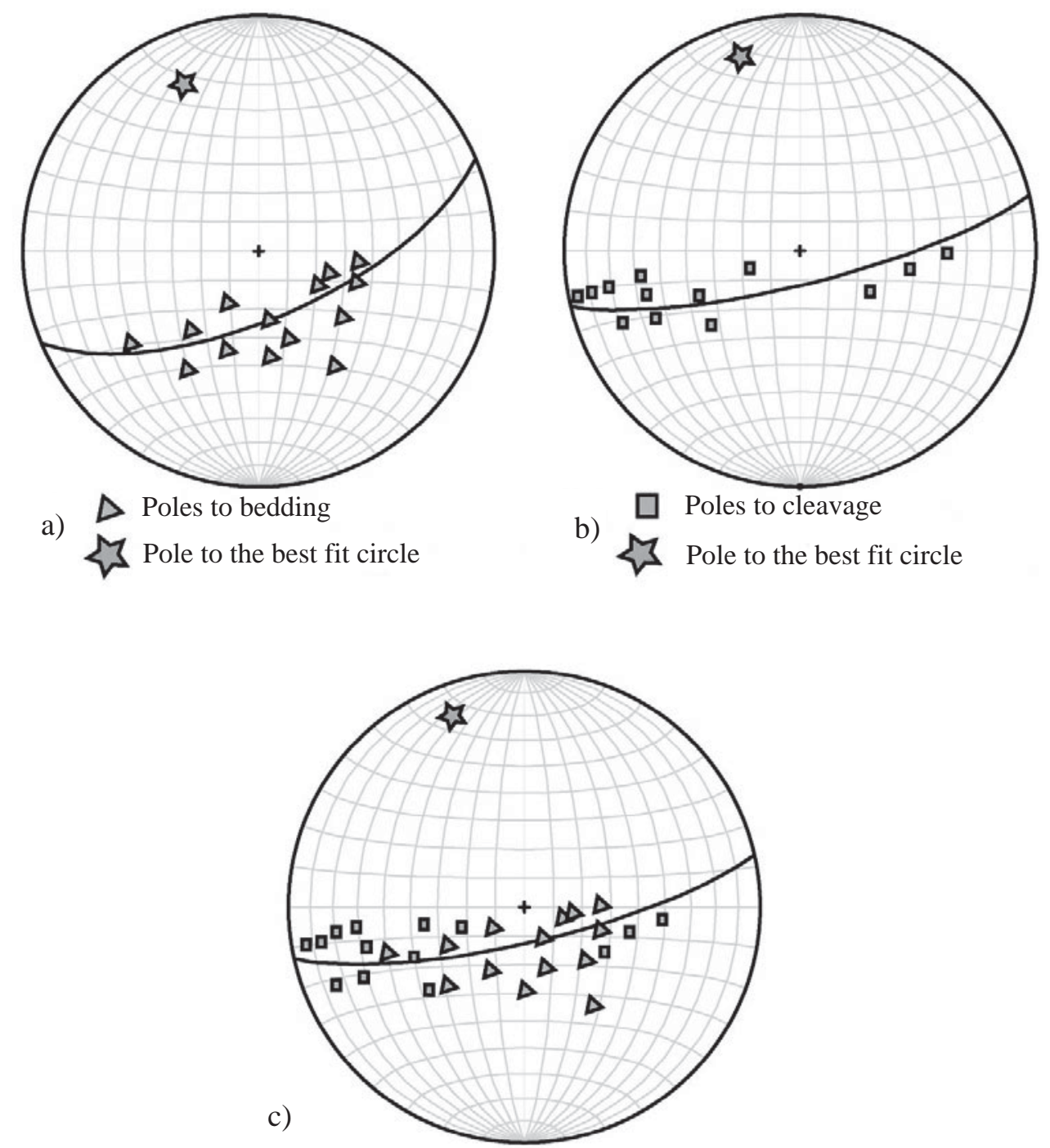

Figure 10. Poles to the bedding in rocks with clevage (a), poles to the clevage planes (b) and the best fit circle to these poles in the East Potrillo Mountains. In c) both bedding and cleavage are plotted together showing that cleavage and bedding are coaxial with folds implying folding and cleavage development occurred synchronously.

series of northwest - southeast striking folds with shallow plunges (Figure 13). Prior workers in the region have concluded that the large syncline - anticline pair west of the Franklin Mountains at Anthony Gap was north - south trending (Lovejoy, 1975; Kelly and Matheny, 1983). This was based largely on the topographic expression of the folds which have a long north - south striking west dipping limb that stretches from Anthony Gap to Tom Mays Park. This gives the impression of a large south plunging syncline. However, careful examination of the map pattern and bedding orientations shows that these folds are the result of at least two phases of deformation (Figure 13 and 14). Bedding measurements from the Hueco group and Panther Seep formation at Anthony Gap, when plotted on stereographic projection, define a great circle girdle which indicates northwest - southeast trending folds with gentle plunges (Figure 14). This map scale fold axis lies parallel to a series of small scale folds, particularly well developed in shale and evaporate beds of the Panther Seep formation (Figure 15). These folds are open to tight, generally verge to the northeast and have shallowly northwest - southeast plunging hinges. Both the map scale folds and outcrop scale folds are interpreted to result from the first phase of folding. The structures of the western side of the Franklin Mountains are the result of either reverse faulting along the western boundary fault zone or it could be the result of tilting of the range during the formation of the Rio Grande rift. No exposures of the western boundary fault zone are found north of Tom Mays Park suggesting the fault zone terminates at this point (Seager, 1981). However, recently reinterpreted seismic data from Web Gap suggests that the western boundary fault system extends in the subsurface 


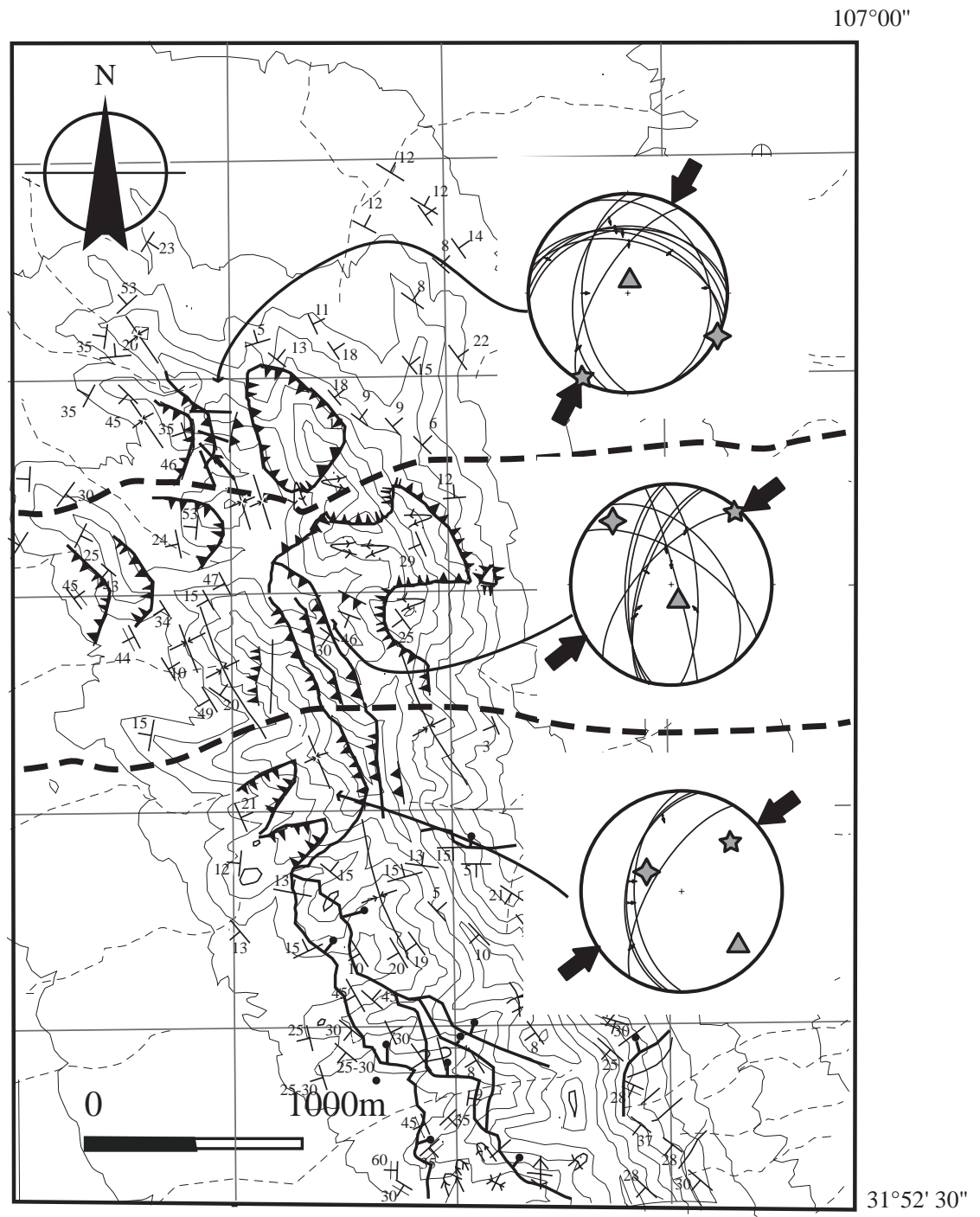

Figure 11. Results of stress inversion using the method of Michael (1984) for three selected locations in the northern Potrillo Mountains. Data are consistent with northeast-southwest horizontal shortening and subvertical extension.

at least as far north as Web Gap in the northern Franklin Mountains (Ruiz, 2004).

Wu (2002) showed that beds adjacent to the Franklin Mountains steepen dramatically as the reverse faults of the western boundary fault zone are approached. This suggests that a large north - trending monoclinal fold associated with western boundary fault zone trends along much of the western flank of the Franklin Mountains. We therefore think it is likely that the monocline in the Hueco formation is a result of reverse faulting along the western boundary fault zone. However, it is likely that tilting and normal faulting amplified this monocline during uplift of the modern Franklin Mountains. Going south from Anthony Gap to Tom Mays Park folds change from northeast vergent to southwest vergent (compare Figure 16a and 16b). This is most obvious in the kilometer scale asymmetric fold found just to the west of Tom Mays Park (Figure 16, a). However, the fold axis in this area parallels folds found at
Anthony Gap, occurs in the same rocks and therefore most likely resulted from the $F_{1}$ folding event.

Several models have been proposed for the formation of the folds between Tom Mays Park and Anthony Gap. Perhaps the most popular and most controversial is that of Lovejoy (1975). He argued that faults and folds in the Franklins resulted from large scale landsliding off of the west tilted Franklin mountains. This conclusion was based on the extension of similar relationships found to the south at Crazy Cat Mountain (southern tip of Franklins) where Paleozoic rocks failed in a catastrophic landslide (Lovejoy, 1975).

However, several features preclude a landsliding origin for these folds. First, the vergence of folds at Anthony Gap is northeast vergent, opposite what is predicted by the land sliding model. Second, faults exposed in gypsum beds of the Panther Seep formation expose a number of features which indicate northeast directed transport during thrust- 
ing, again opposite to that predicted by the land sliding model. These include the development of $\mathrm{C} / \mathrm{S}$ structures in gypsum beds, slickensides with steps indicating northeast transport, and chocolate tablet boudinage of shale beds which record northeast - southwest directed horizontal shortening. Taken together these features indicate that the folds at Anthony Gap resulted form northeast directed thrusting in the hanging wall of a décollement developed in the upper part of the Panther Seep formation. This interpretation provides an explanation for why rocks older than the Panther Seep are not tightly folded since they would have been mechanically detached from the hanging wall during thrusting. The change to southwest vergence at Tom Mays Park and further south is interpreted to result

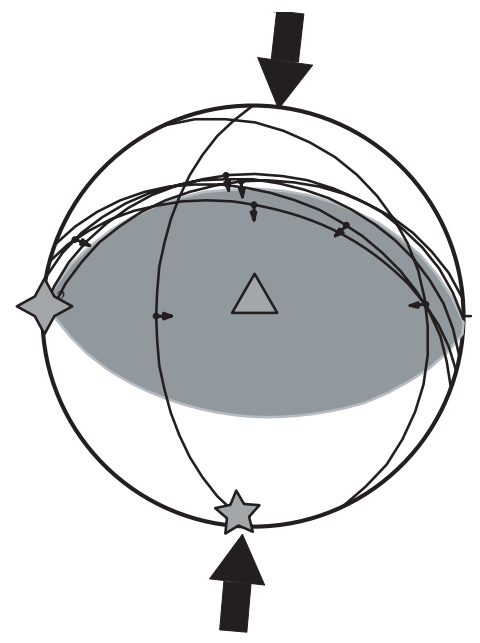

a)
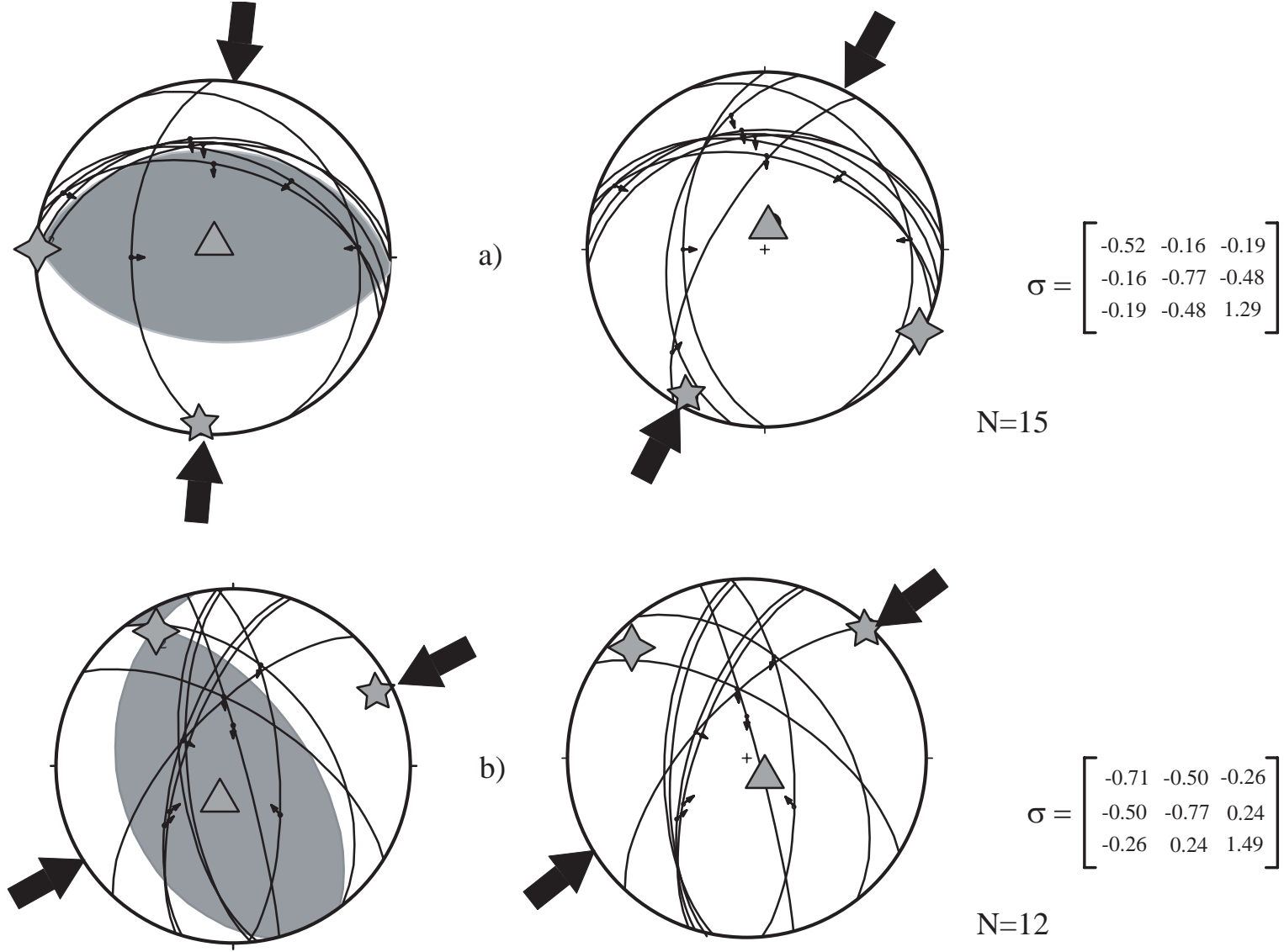

b)

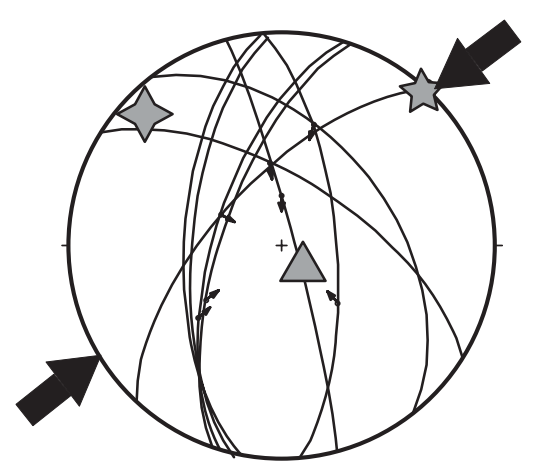

$$
\sigma=\left[\begin{array}{rrr}
-0.71 & -0.50 & -0.26 \\
-0.50 & -0.77 & 0.24 \\
-0.26 & 0.24 & 1.49
\end{array}\right]
$$

$\mathrm{N}=12$
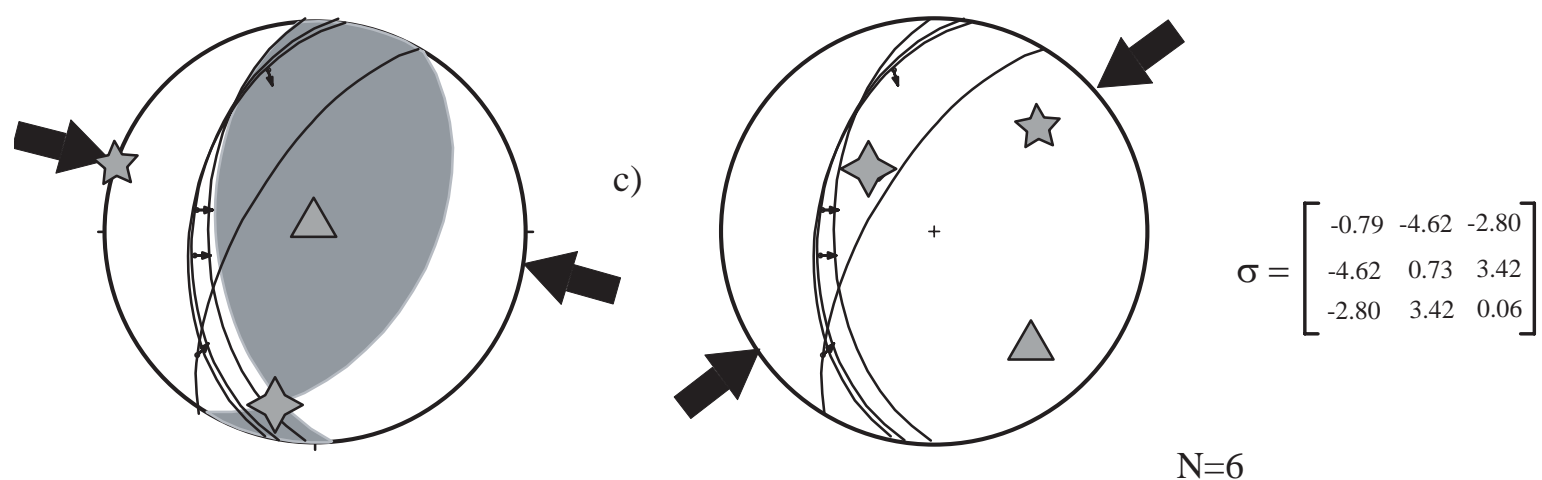

Figure 12. Examples of kinematic analysis via direct and inverse fault - slip stress determination in the East Potrillo Mountains. A, B and C correspond to the northern, central and southern localities shown in Figure 2.11. As can be seen from the data direct and inverse methods give similar results at the three localities shown in figure 2.11. The largest difference comes in the southern location, where the direct inversion method gives a greatest compression axis indicative of west - northwest horizontal compression. This is likely due to the presence of faults with west - northwest plunging slickenisdes at this locality. $\sigma_{1}, \sigma_{2}$ and $\sigma_{3}$ are the principal stress axis of the stress tensor $\left(\sigma_{1}>\sigma_{2}>\sigma_{3}\right)$ represented with five, four and three star points respectively. The first column is the summation moment tensor and the average plane solution is represented as a dihedral equal area projection. The elongation region plotted as dark area. 


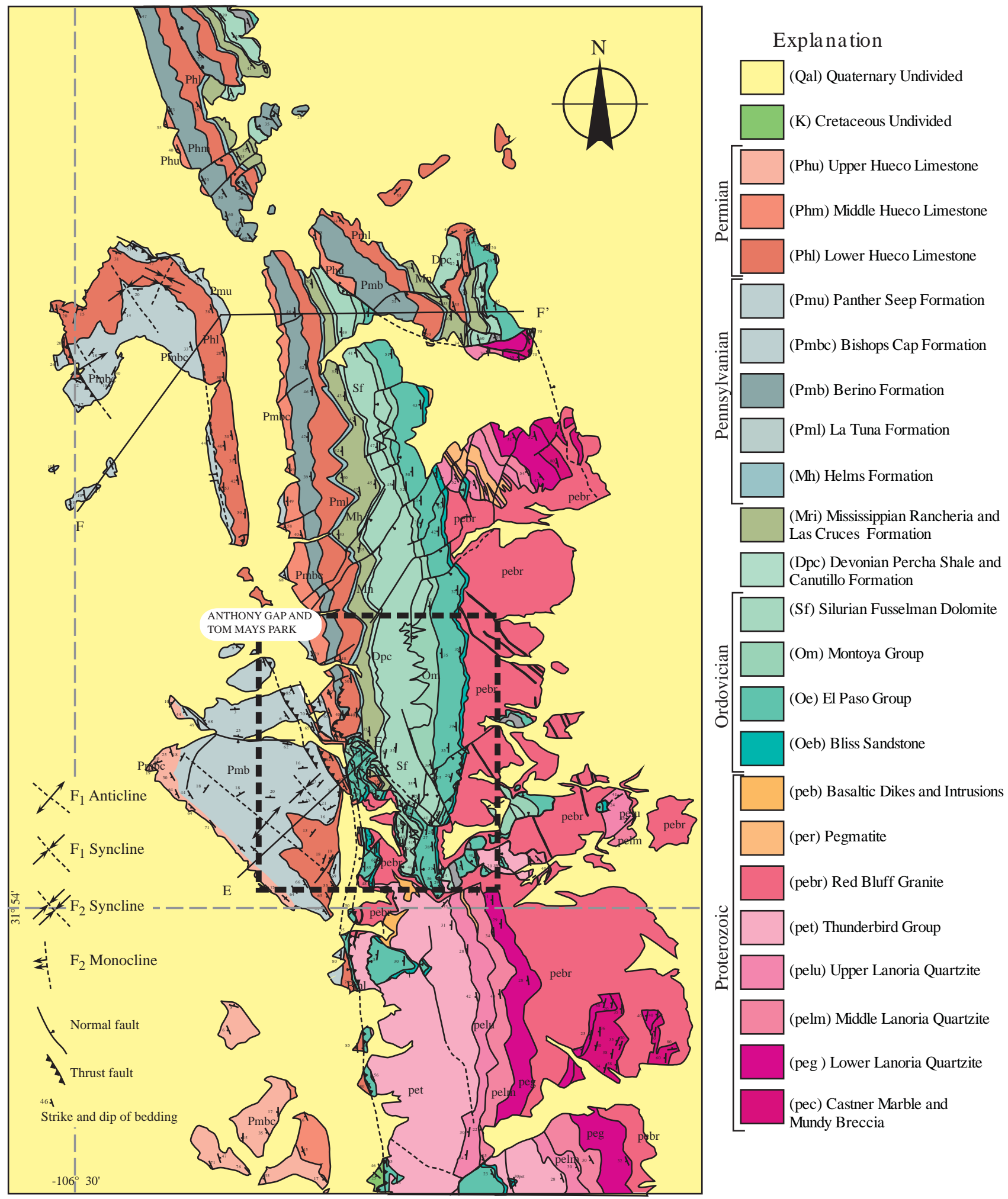

Figure 13. Geologic map of the northern Franklin Mountains from Harbour (1972) and field reconnaissance. 


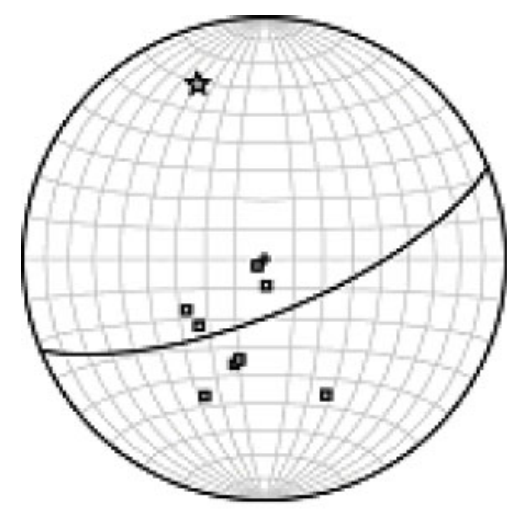

a)

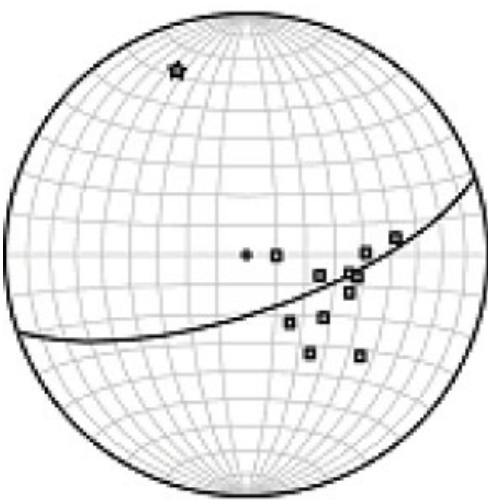

c)

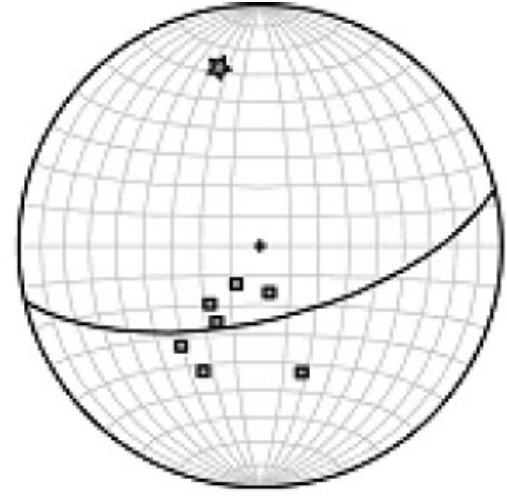

a Poles to beddings Fold axis b)

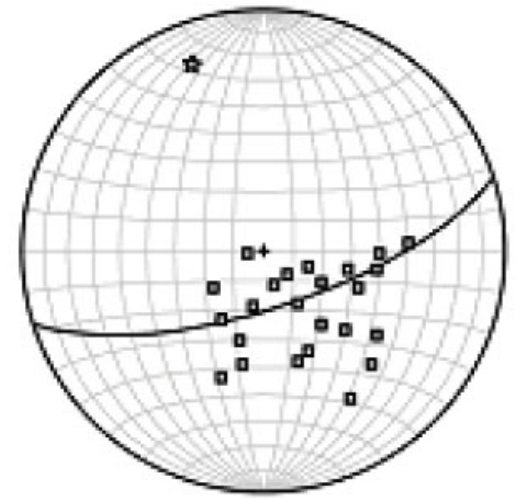

d)

Figure 14. Fold axis SW of Anthony Gap, based on bedding measurements. Panther Seep Formation (a), Bishop Cap Formation (b), Hueco limestone (c). All the poles to bedding were plotted together for a better fit (d).

from back thrusting along the same detachement fault as shortening progressed.

In contrast to the East Potrillo Mountains, few thrust faults are exposed in the Franklin Mountains. This is due partly to Tertiary and Quaternary cover along much of the western Franklin Mountains and a general decrease in the intensity of deformation when compared to the East Potrillo Mountains. The best exposures of thrust faults occur in a series of small quarries south of Anthony Gap, and outcrops in the mouth of Avispa Canyon at the north end of Tom Mays Park (Figure 13). At Anthony Gap the faults are best developed in the evaporate beds of the Panther Seep formation, which are strongly sheared. These rocks contain a series of imbricate flat and ramp structures which show clear northeast vergence. Slickensides are defined by fibers of gypsum developed in shear zones which are generally parallel to bedding. In a number of locations the gypsum rich beds contain a foliation which is oblique to bedding. The obliquity of this fabric is also consistent with northeast directed transport. Inversion of fault slip data in the northern Franklin Mountains shows that the faults formed in response to northeast - southwest directed shortening, nearly identical to the East Potrillo
Mountains (Figure 17).

$\mathrm{Wu}(2002)$ found a similar strain field along the western boundary fault in the Franklin Mountains, where Precambrian and lower Paleozoic rocks form the hanging wall of high angle reverse faults. Additionally, if north trending folds adjacent to the western boundary fault are rotated to correct for extension related tilting of the range, then the folds are subparallel to those found at Tom Mays Park and Anthony Gap (Wu, 2002). This result suggests that faults associated with low angle thrust and high angle reverse faults in the Franklin Mountains resulted from the same progressive deformation event.

\subsection{Cerro de Cristo Rey}

To the southwest of the Franklin Mountains, the Cerro de Cristo Rey exposes the 45 Ma Muleros Andesite which intrudes Cretaceous sedimentary rocks (Lovejoy, 1976). The rocks around the intrusion are strongly deformed by a series of faults and folds that both pre - date and formed synchronously with intrusion of the pluton (Lovejoy, 1976). These rocks provide an important tie as they expose 

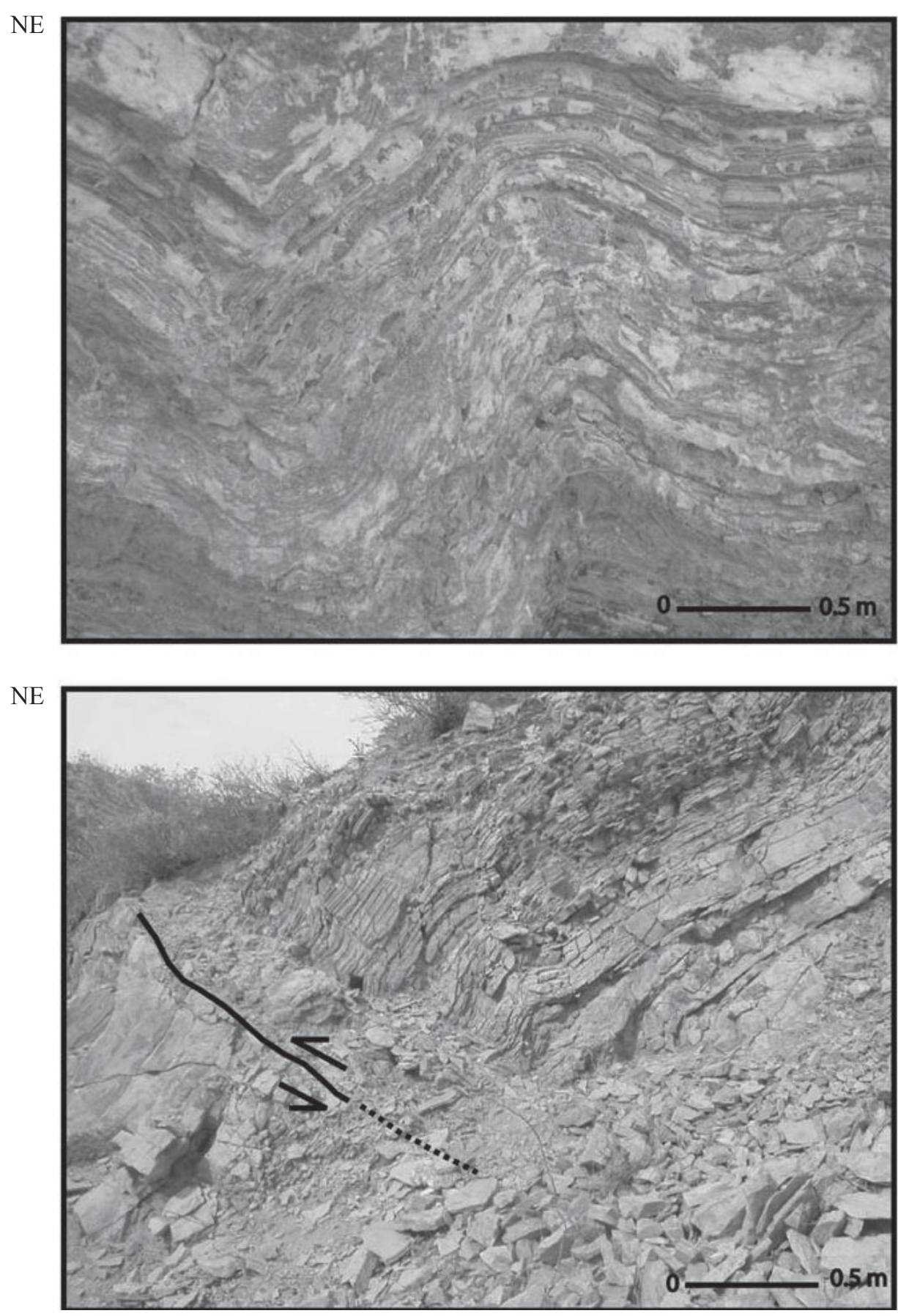

SW

Figure 15. Examples of Laramide deformation at Anthony Gap, Northern Franklin Mountains. a) Northeast vergent fold in gypsum beds in quarry to southwest of Anthony gap. b) Small scale back thrust in gypsum bed shale beds of Panther Seep Formation.

faults and folds of similar style and orientation to both the Franklin and East Potrillo Mountains demonstrating that structures throughout the region record the same deformation event.

Folds, like the Powerline syncline at Cristo Rey (Figure 18) are northwest trending with shallow plunges, similar to folds found in both the Franklin Mountains and the East Potrillo Mountains. The largest difference in the structures at Cristo Rey is that folds trend more westerly than in either the Franklin Mountains or East Potrillo Mountains. This is likely due to modification of the folds during intrusion of the Muleros Andesite, which largely post dated folding (Lovejoy, 1976). Inversion of fault slip data at Cristo Rey also shows the same northeast - southwest directed shortening direction and subvertical extension (Figure 19), confirming that structures across the Laramide structures across the Mesilla Basin record the same contractional strain field. 
a)

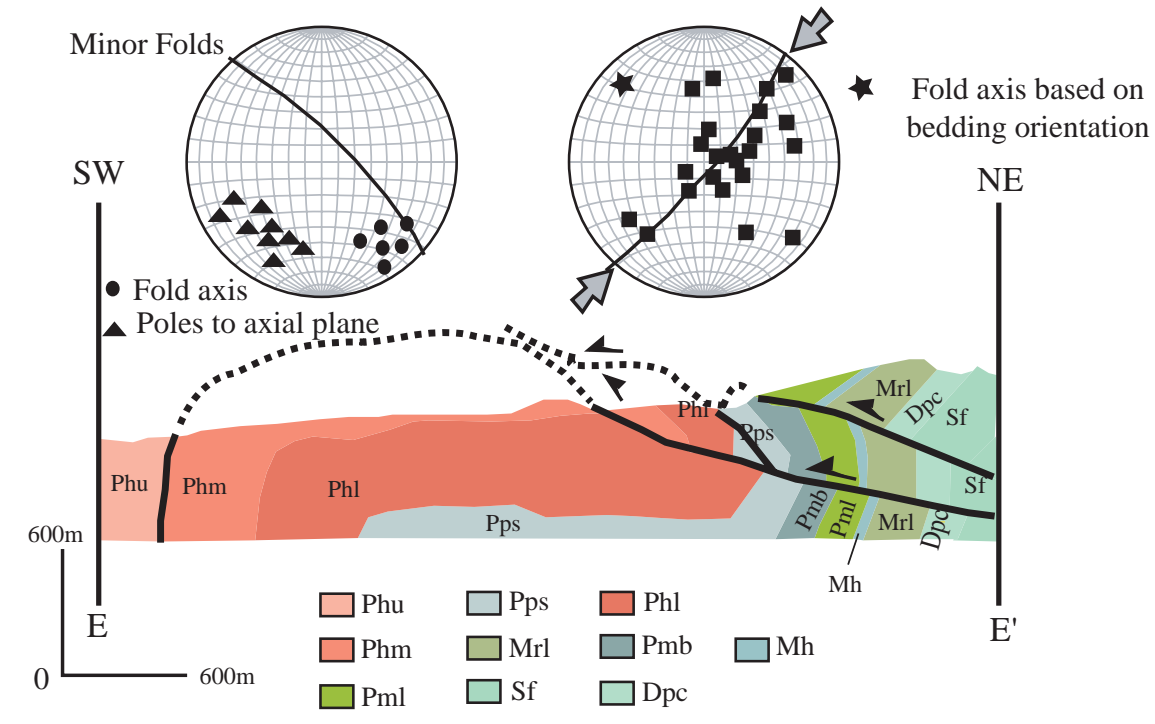

b)

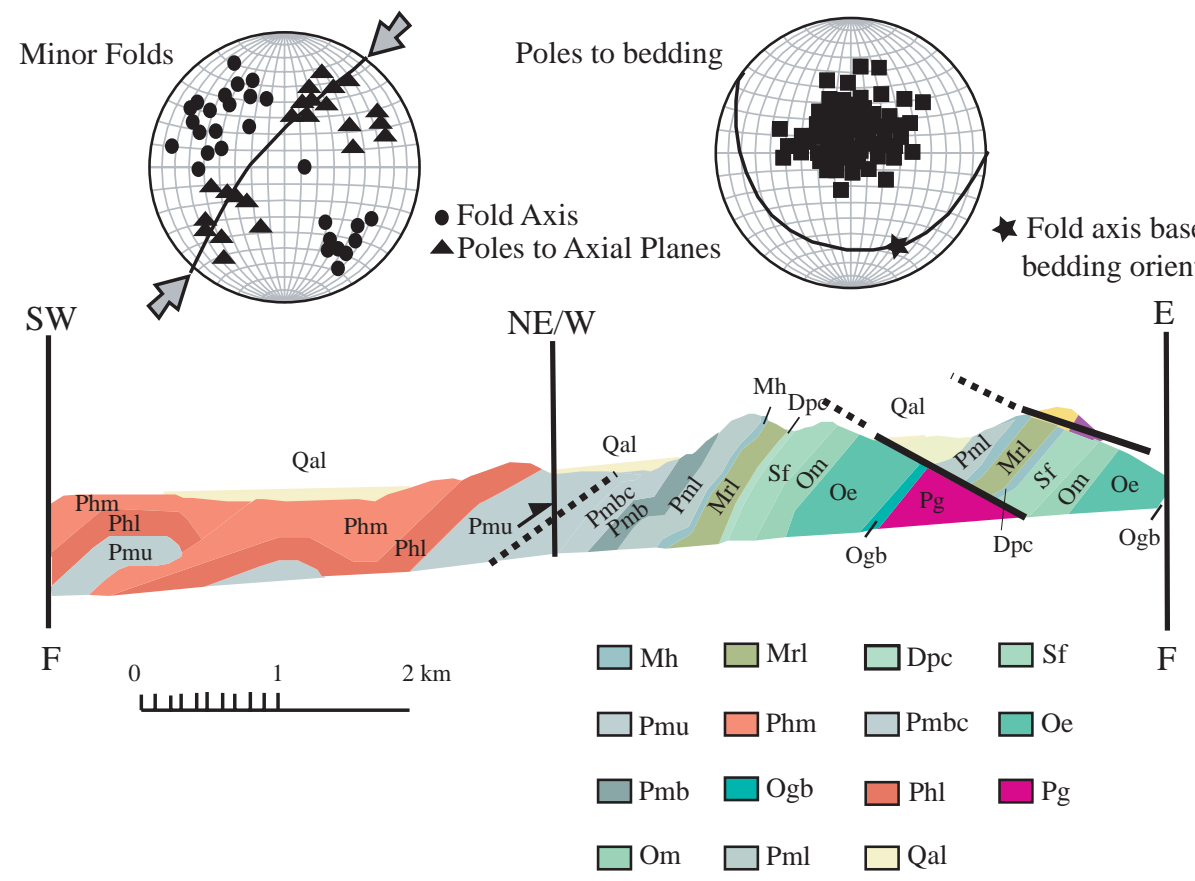

Figure 16. Cross sections of the Northern Franklin Mountains. a) Structure of Tom Mays Park area. b) Structure of Anthony Gap area. Stereographic projections of the fold axes and poles to bedding are lower hemisphere, equal area projections in both a) and b). The shortening direction is indicated.

\subsection{Indio Mountains}

The Indio Mountains are located to the southwest of Van Horn, Texas and form a small range along the U.S - Mexico border. The structural geology of the Indio Mountains has been described by Underwood (1962) and Rohrbaugh (2001), so only the details pertinent to the present study will be reviewed. Thrust faults in the Indio Mountains strike north - northwest and result in stratigraphic repetition of the Cretaceous section. Underwood (1962) estimates a minimum of $8000 \mathrm{ft}$ of stratigraphic repetition in the Indio Mountains and Rohrbaugh (2001) estimated a minimum of six kilometers of displacement along thrusts in the Indio Mountains.

In comparison with Laramide structures found around the Mesilla basin (northern of the trough margin), several important differences are observed. First, folds in the Indio Mountains and adjacent areas trend more northerly (Figure 20). Second, there is abundant evidence for left lateral transpression in the Indio Mountains (Rohrbaugh, 2001), including east - southeast directed transport along thrust faults, clockwise rotation of fold hinges, and local- 

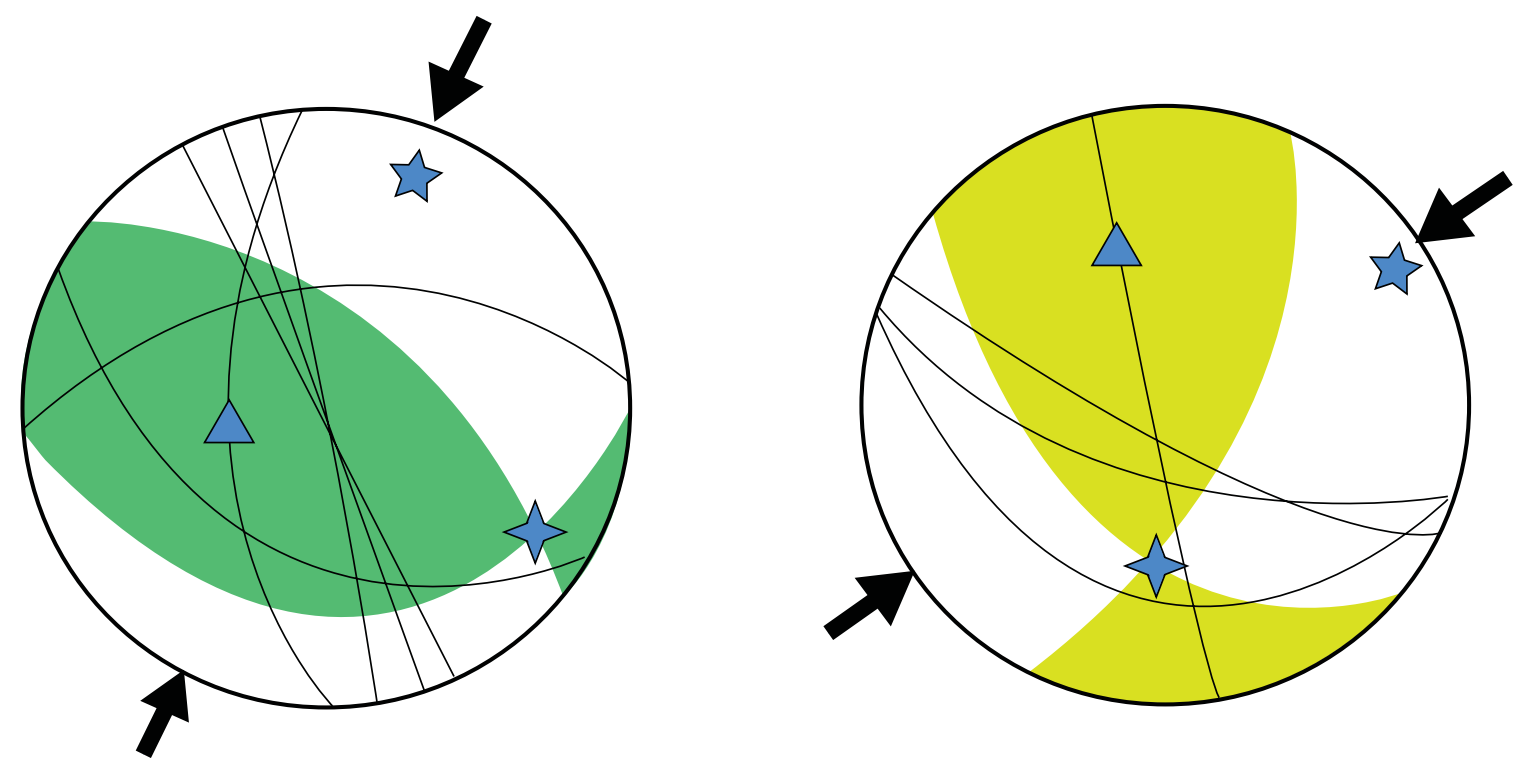

Figure 17. Example of kinematic analysis in the North Franklin Mountains. $\sigma_{1}, \sigma_{2}$ and $\sigma_{3}$ are the stress axis of the stress tensor $\left(\sigma_{1}>\sigma_{2}>\sigma_{3}\right)$ represented with five, four and three star points respectively. Data is consistent with NW-SE shortening.

ly developed small scale strike slip shear zones with left handed sense of displacement. Additionally, in an inversion of fault slip data Rohrbaugh (2001) showed that the greatest compression direction was east - southeast (Figure 20). This contrasts substantially with northeast directed shortening observed to the north in the Franklin and East Potrillo Mountains.

These differences could be due to the Indio Mountains recording a distinct phase of deformation not observed to the north. However, the Laramide structures are developed in Albian - Aptian rocks, similar to the East Potrillo Mountains and Cerro de Cristo Rey and occur below an unconformity with $\sim 36$ Ma welded tuffs, suggesting deformation occurred in the late Cretaceous and early Tertiary, similar to the Franklin and East Potrillo Mountains. Finally, the Indio Mountains occur in nearly the same structural position with respect to the margin of the Chihuahua trough as Cerro de Cristo Rey. Taken together, the data suggest that differences in deformation style between the northern margin of trough and the Indio Mountains are the result of heterogeneous strain during Laramide shortening. This possibility is investigated further below.

\section{Discussion}

Fundamental differences in intensity of deformation and deformation style exist in different regions of the Chihuahua trough. Additionally, the shortening direction estimated for the Franklin and East Potrillo Mountains is northeast - southwest, whereas the shortening direction for the Indio Mountains is east - southeast. Furthermore, the Franklin Mountains expose the transition from thick - skinned thrusting typical of the Laramide orogen, whereas the East Potrillo and Indio Mountains expose a thin skinned deformation style more typical of the Cordilleran orogen. These fundamental differences in deformation are closely related to the geometry of the Chihuahua trough, particularly the strike of its eastern margin and the thickness of the sedimentary section within the trough.

Figure 4 shows an isopach map for the base of the lower Cretaceous. Also shown are Rose diagrams which show the orientations of map scale folds in the northern portion of the trough and the eastern margin of the trough near the Indio Mountains. These Rose diagrams were constructed from the map in Figure 3, by measuring the trend of map scale folds in 5 kilometer increments. Folds that curved more than five degrees (the size of the rose petals) were not plotted. Note that in the northern part of the Chihuahua trough folds trend to 325, whereas in along the trough's southeast side, the folds trend to 346 . These differences in fold trend coincide with changes in the trends of the isopachs, which are generally northwest trending in the north and north - northwest trending in the south (compare Figure 3 and 4). This geometric relationship indicates the geometry of the trough's eastern margin imposed a profound influence on the development of the folds and related faults.

Another feature which is apparent from the isopach map is that the regions which have a thin - skinned structural style are restricted to areas where the Cretaceous section is thicker than $300 \mathrm{~m}$, whereas regions which have basement involved faulting, the Cretaceous section is or absent. This is true not only for the regions described here, but also regionally. Seager and Mack (1985) showed that the 

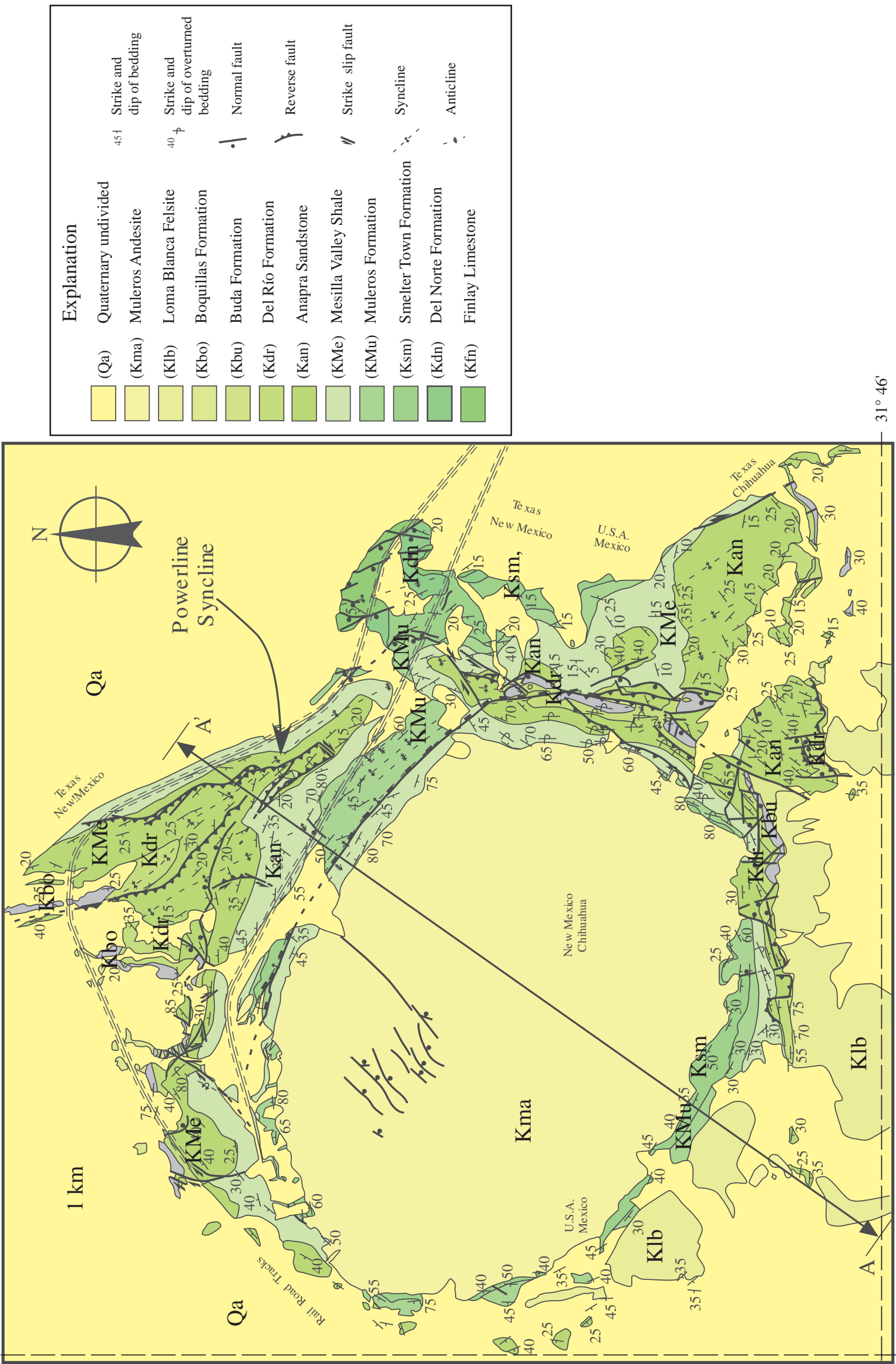


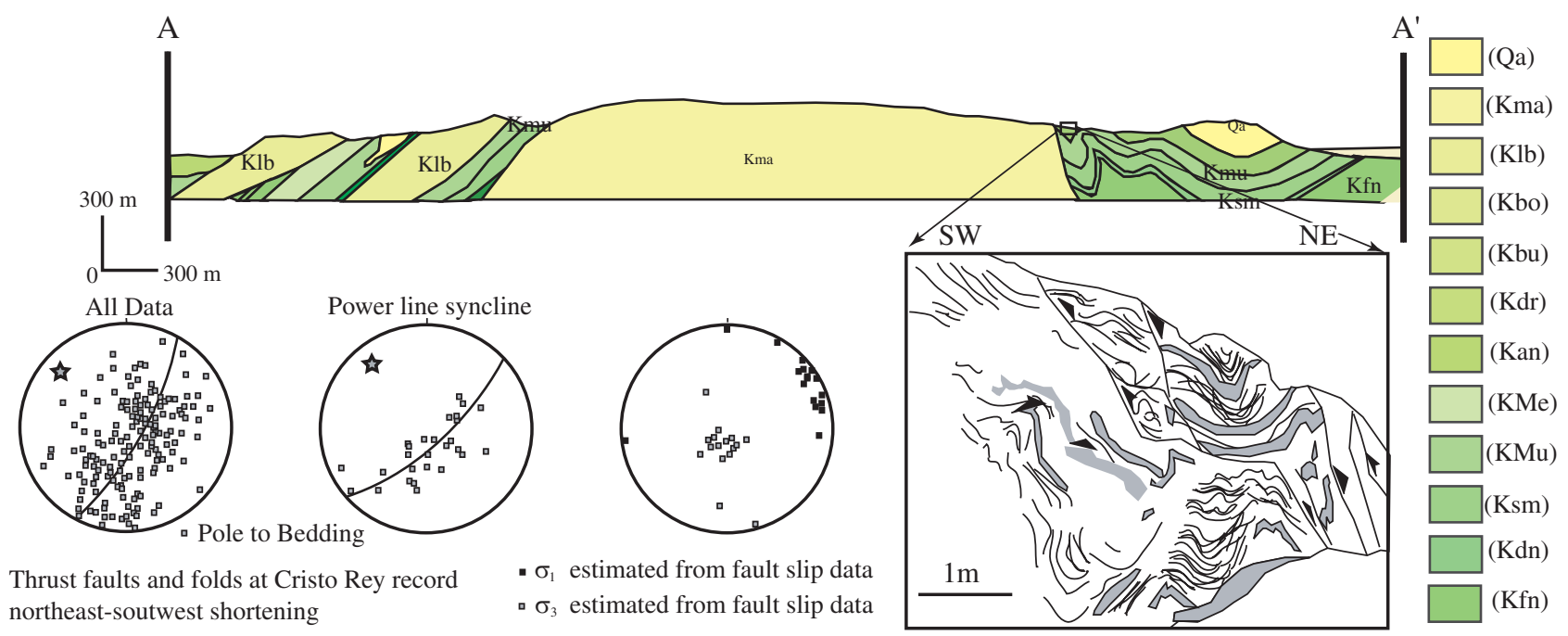

Figure 19. Geological cross - section of Cerro de Cristo Rey uplift based on map of Lovejoy (1980). Stereonets showing poles to all bedding planes consistent with northwest plunging map scale folds. Estimates of the orientations of greatest compression and least compression directions based on inversion of fault slip data, consistent with northeast-southwest directed compression and subvertical extension. Sketch shows geometry of folds in the Mesilla Valley shale on southwest limb of Powerline syncline adjacent to the Muleros Andesite showing intense deformation of shale.

Burro uplift of southwestern New Mexico contains clear evidence of basement involved thrusting. This region was a high during the Cretaceous and lies outside of the region of Cretaceous sedimentary rocks (Figure 4). Directly north of the Franklin Mountains, the Bear Peak fault zone places Proterozoic basement over Paleozoic rocks and is therefore thick - skinned, and again lower Cretaceous sedimentary rocks are absent. These relationships indicate that the thin - skinned style of deformation is restricted to areas where the Cretaceous sedimentary section is present. The one exception to this is along the western flank of the Franklin Mountains where thin - skinned detachment style folds are found in Permian and Pennsylvanian rocks. However, as shown above, these folds are developed above thin bedded shales and evaporate beds of the Panther Seep formation, which are mechanically similar to the Cretaceous section. Taken together, the data indicate that the preexisting geometry of the Chihuahua trough placed a profound control on the intensity, style and orientation of Laramide structures along the margin of the Chihuahua trough. A simple model that compares the thin- and thick- skinned relations with sedimentary thickness is presented in Figure 21.

The strong geometric relationships between the geometry of the trough and the style of Laramide deformation suggests that there may be a fundamental mechanical control on deformation imposed by the anisotropy inherited from the trough. The sediments found within the trough are generally interbedded sandstones, shales, and limestones, with shales accounting for $1 / 3$ to $1 / 2$ of the exposed section. These sequences of Cretaceous rock are floored by Jurassic evaporates throughout much of the Chihuahua trough (Gries, 1970). These evaporates have acted as detachment surfaces above which the Cretaceous section has folded during shortening. Additionally, our observations in the East Potrillo and Franklin Mountains show that ductile deformation is focused within shales and evaporates suggesting lithological controls on deformation partitioning. Shortening directions inferred from fold trends and fault slip inversions are nearly perpendicular to the troughs margin along its length between the East Potrillo Mountains and Indio Mountains. This is despite there being a nearly $30^{\circ}$ difference in the orientation of the margin of the trough between the north and south. This high angle relationship and change from strain dominated by northeast - southwest directed horizontal shortening (Franklin and East Potrillo Mountains, Cerro de Cristo Rey) to left lateral transpression (Indio Mountains) indicate along strike variations in the strain field that coincide with changes in the geometry of the trough's margin.

Harland (1971) presented a simple kinematic model for variation in kinematics around curved deformation zones (Figure 22, a). According to this model, transpression occurs along margins which are oblique to the shortening direction whereas convergence occurs in regions that are at a high angle to the transport direction. Assuming an east - northeast shortening direction for the Laramide orogeny (Bird, 1998) and applying Harland's geometric model predicts that the region around El Paso should record left lateral transpression and the region near the Indio mountains should be contractional or undergoing right lateral transpression. Instead, the observed deformation patterns show dominantly contractional strains near El Paso and left lateral transpression in the Indio Mountains. Clearly, the model of Harland (1971) does not fit the observed pattern of deformation in the Chihuahua trough.

It is a well known that weak interfaces focus deformation 


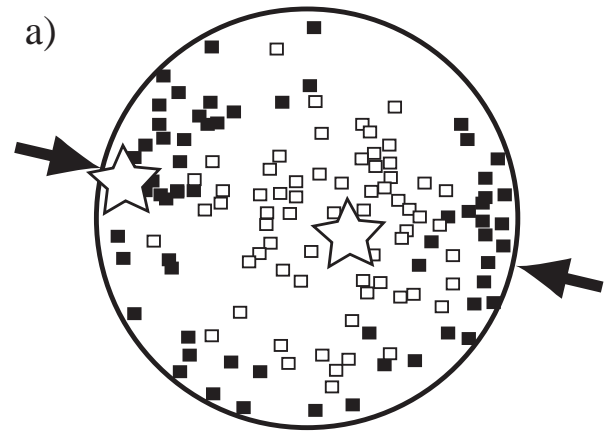

Incremental stretching axis

Incremental shortening axis

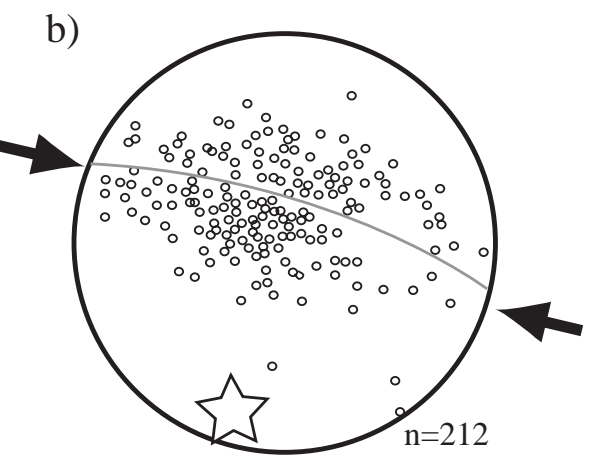

- Poles to bedding

Figure 20. Stereonets summarizing structural data from the Indio Mountains, modified from Rohrbaugh, (2001). a) Compression and tension axis estimated from fault slip data using the inversion method of Marrett and Allmendinger (1991). Average greatest shortening direction is indicated by star marked " $z$ ", and average least shortening direction is indicated by star marked " $x$ ". b) Poles to bedding with best fit great circle shown, star indicates inferred fold axis. Both sets of data are consistent with west-northwest, east - southeast directed shortening and subvertical extension.

and lead to reorientation of stress fields such that the shortening direction is at a high angle or perpendicular to the weak interface (Mount and Suppe, 1987). We infer that the occurrence of evaporates and shales along the trough's margin lead to focusing of deformation into the trough which was weak relative to the adjacent platform and the along strike differences of shortening direction. The shortening direction was forced to be nearly perpendicular to the margin because of the weak interface. This process provides a ready explanation for the along strike variations in shortening direction and kinematics as well as a mechanism to focus deformation within the weak interior of the trough. We suspect that this process may be common in many foreland basin settings where weak sedimentary sections abut stronger platforms. This process is likely to be more apparent where basin margins are curved and may lead to the development of oroclines in fold belts.

An additional feature of the trough which appears to be controlled by the geometry of the basin is the presence of younger on older thrusting along the margin of the trough. It is clear from the map pattern in Figure 3 that from the interior of the Chihuahua trough Cretaceous rocks have been telescoped over Permian and older Paleozoic rocks. This is somewhat counter to normal thrust situations where older rocks are typically thrust over sequences of younger rocks (Suppe, 1985). However, in the case of the Chihuahua trough, the thick sequences of Cretaceous rocks adjacent the Diablo Platform produced a situation where out of basin thrusting resulted in younger rocks piling up on older sequences of rocks. Thus, the unusual situation where
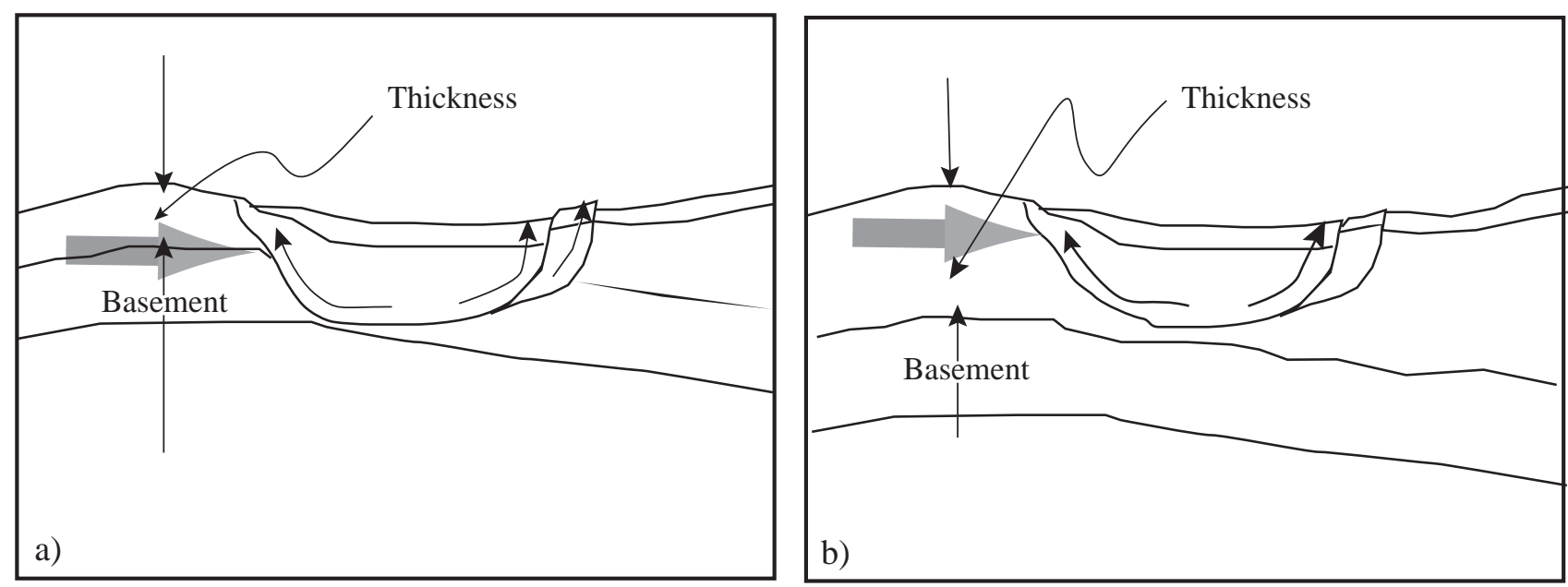

Figure 21. Thick- and thick- skinned models. a) Thick skinned deformation (basement involved) is controlled by the relative small thickness of the Cretaceous sedimentary layer and b) thin skinned occurs when the Cretaceous sedimentary layer is thicker than $300 \mathrm{~m}$. 


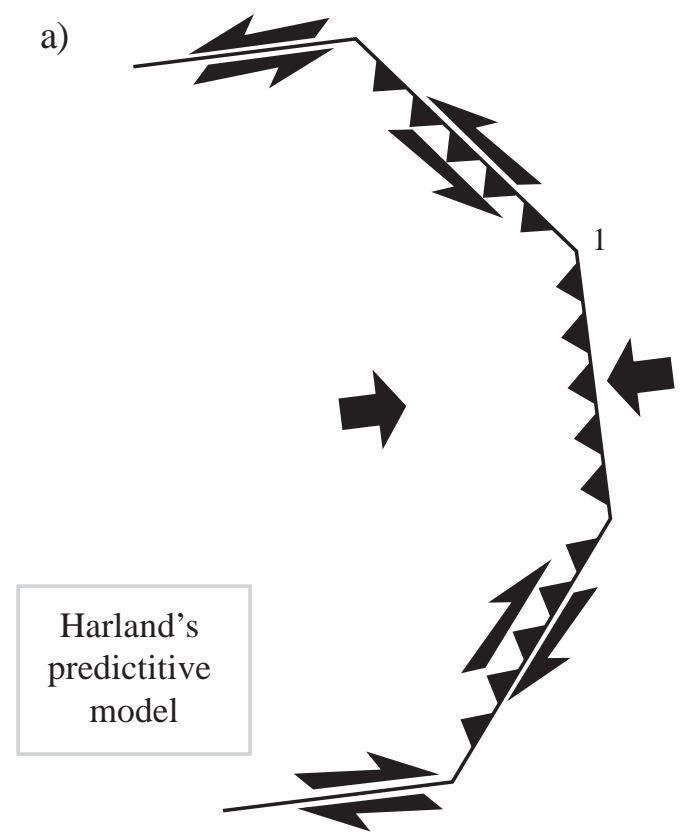

b)

Figure 22. a) Diagram showing displacement pattern predicted from application of Harland's (1971) kinematic model for curved displacement belts. b) Observed kinematic pattern along margin of Chihuahua trough. Large arrows show displacement direction inferred for Laramide deformation (Bird, 1998).

younger rocks are thrust over older rocks is also explained by the presence of a thick Cretaceous section adjacent to an older platform sequence.

A final observation is that the geometry of the Chihuahua trough was largely controlled by the geometry of Jurassic through Cretaceous normal faults which led to the initial subsidence of the trough (Uphoff, 1978). This initial geometry of the basin then strongly influenced the development of Laramide structures. We suspect that much of the complexity observed in deformed foreland basins may result from the initial geometry of the basins.

The results of this study are summarized in Table 1. The Laramide deformation and magmatic activity have been attribuited to a change in the convergence rate between the Farallon and the North American plates. Moreover, the most accepted cause of this major deformation has been attributed to flattening of the subduction of the Farallon plate.

\section{Conclusions}

The Chihuahua trough is a major Mesozoic basin along the U.S - Mexico border between El Paso and Big Bend, Texas. The initial geometry of the basin strongly influenced the tectonic development of the Chihuahua trough during Laramide shortening. Thickness variations lead to thin - skinned deformation being focused within the interior of the basin, whereas basement involved deformation typical of the Laramide orogen was restricted to regions found where the Cretaceous section is thin or absent. This variation also influenced intensity of deformation with the most strongly deformed rocks being found in the basin interior. Additionally, the geometry of the basin margin, where weak sedimentary rocks abut a stronger platform caused the shortening direction to maintain a high angle to the basin margin independent of far field stresses. These effects are likely to be common in deformed foreland basin settings and may be an underling cause of deformation patterns in foreland basins.

For the Laramide compressional event, the results show a NE-SW orientation of the shortening direction along the northern margin of the Chihuahua trough (East Potrillo Mounatins, Franklin Mountains and Cerro de Cristo Rey) and a change to E-SE, going to the south along the margin of the trough (Indio Mountains). These differences in the orientation of the shortening direction can be explained based on the geometry of the trough and especially the strike of its eastern margin. Another factor which has to be taken into account is the rock mechanics. The sediments which compose Chihuahua trough are Cretaceous interbedding sandstone, shales, and limestone floored by Jurassic evaporates. These relatively weak sediments enter in contact with the stronger Precambrian basement and Paleozoic carbonate rocks of the Diablo Platform. The contact in between these two interfaces generates a principal plane of stress and the shortening direction was forced to be at high angles or almost perpendicular to this principal plane. Therefore, the chane in strike along the margin of the trough will result in a change of orientation of the shortening direction along the rim of the Chihuahua trough when approached from the north to the south. 
Table 1. Summary of the main tectonic events in the studied region.

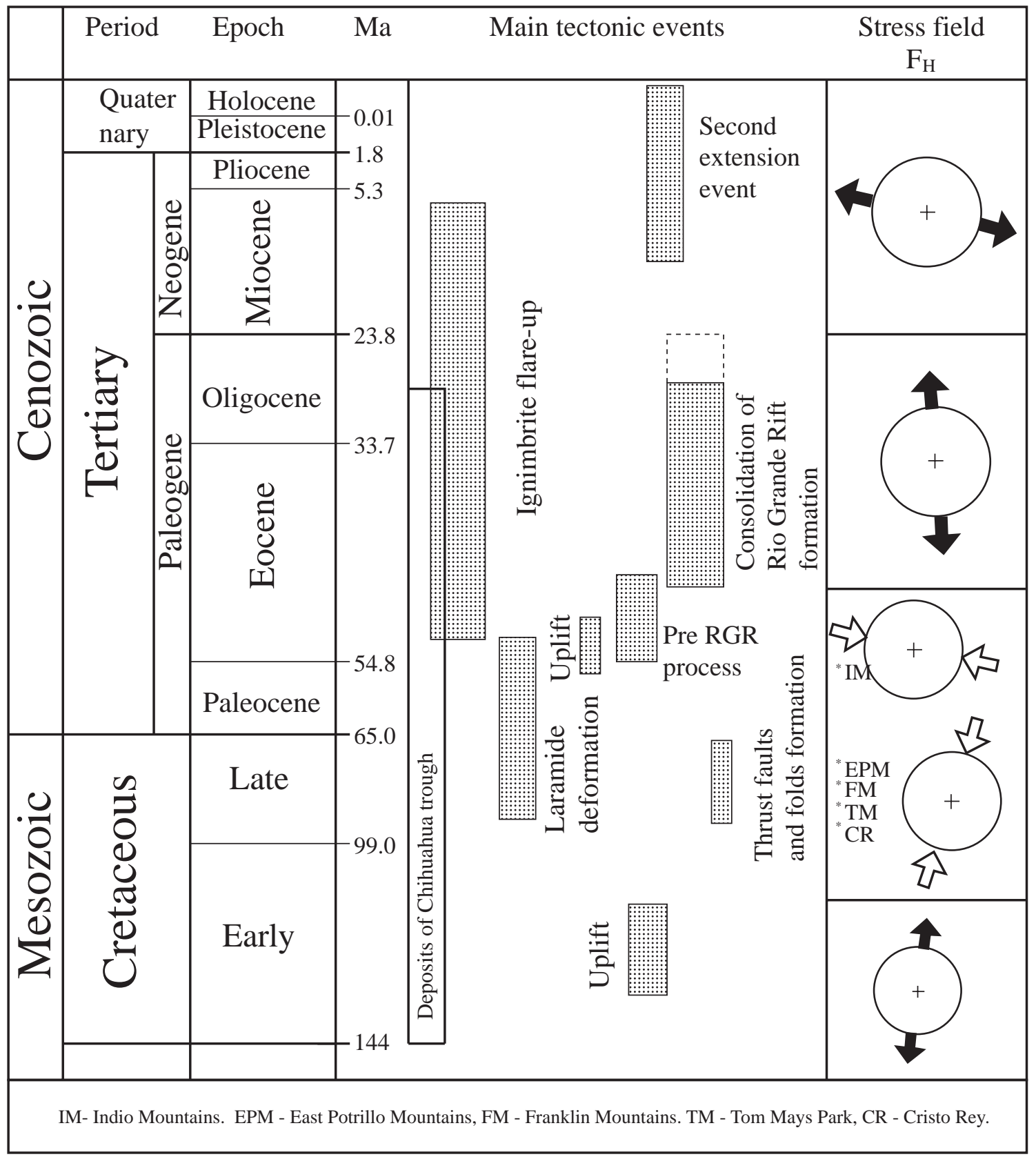

\section{Acknowledgments}

This article was part of a Ph.D thesis (D.C) at the University of Texas at El Paso under the supervision of Christopher Andronicos, who is greatly thanked for his assistance. The comments of Walter Haenggi, Elisa Fitz-Diaz and Antonio CamprubÍ helped us to improve the presentation of this work. This article was funded by National Science Foundation (USA) and National Council of Science and Technology CONACYT (Mexico) in collaboration between The University of Texas at El Paso and CICESE to study the structure of northern Mexico.

\section{Bibliographic references}

Allmendinger, R. W., 2002-2003. Stereowin, Stereonet for Windows V.1.2 http://www.geo.cornell.edu/geology/ faculty/RWA Allmendinger, R. W., 2001. FaultKinWin, a program for analyzing fault slip data for Windows computers. http://www.geo.cornell.edu/geology/facultyRWA/maintext.html

Angelier, J., 1984. Tectonic analysis of fault slip data sets. Journal of Geophysical Research, 89, 5835-5848.

Bird, P., 1988. Formation of the Rocky Mountains, western United States: A continuum computer model. Science, 239, 1501-1507.

Bird, P., 1998. Kinematic history of the Laramide orogeny in latitudes $35^{\circ}$ $-49^{\circ} \mathrm{N}$, western United States. Tectonics, 17, 780-801.

Broderick, J. C., 1984. The geology of Granite Hill, Luna County, New 
Mexico. Master's thesis, University of Texas at El Paso.

Brown, G. A., Clemons, R. E., 1983. Florida Mountains section of southwest New Mexico overthrust belt - a reevaluation. New Mexico Geology, 5, 26-29.

Cather, S. M., 1999. Implications of Jurassic, Cretaceous and proterozoic piercing lines for Laramide oblique-slip faulting in New Mexico and rotation of the Colorado Plateau. Geological Society of America Bulletin, 111, 849-868.

Cather, S. M., 2001. North-South differences in timing and style of ancestral Rocky Mountains deformation, southwestern North America. Abstracts with Programs, Geological Society of America, 33, p.45.

Chapin, C. E., Seager, W. R., 1975. Evolution of the Rio Grande rift in the Socorro and Las Cruces areas. New Mexico Geological Society, Guidebook $26^{\text {th }}$ Field Conference, 297-321.

Chapin, C. E., Cather, S. M., 1981. Eocene tectonics and sedimentation in the Colorado Plateau - Rocky Mountain area. Arizona Geological Society Digest, 14, 173-198.

Coney, P. J., 1972. Cordillerian tectonics and North American plate motion. American Journal of Science, 272, 603-628.

Coney, P. J., 1978. The plate tectonic setting of southeastern Arizona In: Callender, J. F., Wilt, J. C., Clemons, R. E., (Eds.), Land of Cochise. New Mexico Geological Society 29th Field Conference Guidebook, 285-290.

Corbitt, L. L., Woodward, L. A., 1973. Tectonic framework of Cordillerian foldbelt in southwestern New Mexico. Association of American Petroleum Geologists Bulletin, 57, 2207-2216.

DeFord, R. K., 1964. History of geologic exploration in Chihuahua, in Geology of Mina Plomosas-Placer de Guadalupe area, Chihuahua, Mexico. West Texas Geological Society, Field Trip Guidebook 6450, 116-129.

Dickinson, W. R., Snyder, W. S., 1978. Plate tectonics of the Laramide Orogeny. Geological Society of America Memoir, 151, 355-366.

Drewes, H. D., 1982. Some general features of the El Paso - Wickenberg transect of the Cordillerian orogenic belt, Texas to Arizona. Rocky Mountain Association of Geologists, 26, 87-96.

Drewes, H. D., 1988. Development of the foreland zone and adjacent terranes of the Cordilleran orogenic belt near the U.S-Mexican border. Geological Society of America Memoir, 171, 447-463.

Drewes, H.D., Dyer, R., 1993. Geological map and structural sections of the Sierra Juarez, Chihuahua, Mexico. Miscellaneous Investigations Series - U.S Geological Survey Report: I - 2287, 2 sheets.

Erslev, E. A., 1993. Thrust, back-thrust, and detachment of Laramide foreland arches. In: Schmidt, C. J., Chase, R., Erslev, E. A., (Eds.), Laramide basement deformation in the Rocky Mountains foreland of the western United States. Geological Society of America Special Paper, 280, 339-358.

Erslev, E. A., Rogers, S. A., 1993. Basement - covered geometry of Laramide fault - propagation folds. Geological Society of America Special Paper, 280, 125-146.

Erslev, E. A., 2001. Multistage, multidirectional tertiary shortening and compression in north-central New Mexico. Geological Society of America Bulletin, 113, 63-74.

Gries, J. C., 1970. Geology of the Sierra de la Parra area, northeast Chihuahua, Mexico. Ph.D. thesis, University of Texas at Austin.

Gries, J. C., and Haenggi, W. T., 1970. Structural evolution of the eastern Chihuahua tectonic belt. In: Seewald, K., Sundeen, D., (Eds.), The Geologic Framework of the Chihuahua Tectonic Belt. West Texas Geological Society 71-59, 119-137.

Haenggi, W. T., 2001. Tectonic history of the Chihuahua trough, Mexico and adjacent USA, Part I: the pre Mesozoic setting. Boletin de la Sociedad Geologica Mexicana, LIV, 28-66.

Haenggi, W. T., 2002. Tectonic history of the Chihuahua trough, Mexico and adjacent USA, Part II: Mesozoic and Cenozoic. Boletin de la Sociedad Geologica Mexicana, LV, 38-94.

Hamilton, W. B., 1988. Laramide crustal shortening. Geological Society of America Memoir, 171, 27-39.

Harbour, R. L., 1972. Geology of the northern Franklin Mountains, Texas and New Mexico: U.S Geological Survey Bulletin 1298, 129 p.

Harland, W. B., 1971. Tectonic transpression in Caledonian Spitsbergen.
Geological Magazine, 108, 27-41.

Jones, C. H., Sonder, L. J, and Unruh, J. R., 1998. Lithospheric gravitational potential energy and past orogenesis: Implications for conditions of initial Basin and Range and Laramide deformation. Geology, v. 26, 639-642.

Karlstrom, K. E., Daniel, C. G., 1993. Restoration of Laramide right lateral strike slip in northern New Mexico using Proterozoic piercing points: tectonic implication from the Proterozoic to the Cenozoic. Geology, 21, 1139-1142.

Kelley, S. A., Matheny, J. P., 1983. Geology of Anthony Gap quadrangle, Dona Ana County, New Mexico. New Mexico Bureau Mines Mineral and Resources Geologic Map 54, scale 1:24,000.

LeMone, D. V., Kondelin, R., McEvers, H., Madden, D., Roark, R. C., Simpson, R. D., Pickens, C. A., 1983. Paleozoic and Early Cretaceous Isopach Studies of the Southwest Border Region, In: Clark, K. F., Goodell, P. C., (Eds.), Geology and Mineral Resources of North-Central Chihuahua. El Paso Geological Society Guidebook

Livaccari, R. F., 1991. Role of crustal thickening and extensional collapse in the tectonic evolution of the Sevier - Laramide orogeny, Western United States. Geology, 19, 1104-1107.

Lovejoy, E. M. P., 1975. An interpretation of the structural geology of the Franklin Mountains, Texas. New Mexico Geological Society Guidebook, 26, 261-268

Lovejoy, E. M. P., 1976. Geology of Cristo Rey uplift, Chihuahua and New Mexico. New Mexico Bureau of Geology and Mineral Resources Memoir, 31, 84p.

Lovejoy, E. M. P. (Ed.), 1980. Sierra de Juarez Chihuahua Mexico: Structure and Stratigraphy. El Paso Geological Society Guidebook.

Mack, G. H., 2004, The Cambro- Ordovician Bliss and Lower Ordivician El paso formations, southwestern New Mexico and west Texas. In: Mack, G. H., Giles, K. A., The geology of New Mexico, Geological History. New Mexico Geological Society Special Publication, 11, $35-45$

Marrett, R. A., Allmendinger, R. W., 1991. Estimates of strain due to brittle faulting: sampling of fault populations. Journal of Structural Geology, 13, 727-738.

Maxson, J. A., Tikoff, B., 1996. A hit and run collision model for the Laramide Orogeny, Western U.S, Geology, 24, 968-972.

Michael, A. J., 1984. Determination of stress from slip data: faults and folds. Journal of Geophysical Research 89, 11,517-11,526.

Mount, V. S., Suppe, J., 1987. State of stress near the San Andreas fault - Implications for wrench tectonics. Geology, 15, 1143-1146.

Muehlberger, W. R., 1980. Texas lineament revisited. In: Dickerson, P.W., Hoffer, J.M., Callender, J.F., (Eds), Trans-Pecos region, southeastern New Mexico and West Texas. New Mexico Geological Society, Guidebook 31, 113-121.

Oldow, J. S., Bally, A. W., Lallemant, A., Hans, G., 1990. Transpression, orogenic float and lithospheric balance. Geology, 18, 991-994.

Petite, J. P., 1987. Criteria for the sense of movement on fault surface in brittle rocks. Journal of Structural Geology, 9, 597-607.

Ramsay, J. G., Huber, M.I., 1983. The techniques of Modern Structural Geology. Strain Analysis. Academic Press.

Ramsay, J. G., Lisle, R., 1997. Techniques of Modern Structural Geology, volume 3. Academic Press.

Reaser, D. F., 1982. Geometry and deformational environment of the Cieneguilla-Quitman range in northeastern Chihuahua, Mexico and Western Trans-Pecos, Texas, U.S.A. Rocky Mountain Association of Geologists, 26, 425-449.

Rohrbaugh, R., 2001. Contractional and extensional deformation, kinematics of the southern Indio Mountains, Trans Pecos. Master's thesis, Univerity of Texas at El Paso.

Ruiz, A., 2004. An integrated analysis of the Laramide orogeny, and the effects of the Rio Grande rift in southern New Mexico and west Texas. Master's thesis, Universty of Texas at El Paso.

Seager, W. R., 1975. Cenozoic tectonic evolution of the Las Cruces area. New Mexico Geological Society 26th Annual Fieltrip Guidebook, 297-321.

Seager, W. R., 1981. Geology of the Organ Mountains and southern San 
Andres Mountains, New Mexico. New Mexico Bureau of Mines and Mineral Resources Memoir 36, 1-97.

Seager, W. R., Mack, G. H., 1985. Laramide Paleotectonics of Southern New Mexico. American Association of Petroleum Geologists, Memoir 41, 669-685.

Seager, W. R., Mack, G. H., 1994. Geology of East Potrillo Mountains and vicinity, Dona Ana County, New Mexico. New Mexico Bureau of Mines and Mineral Resources Bulletin, 113.

Suppe, J., 1985. Principles of Structural Geology. Prentince Hall, 537p.

Suppe, J., Medwedeff, D., 1990. Geometry and kinematics of faultpropagation folding: Eclogae Geologicae Helvetiae, 83, 409-454.

Tikoff, B., Maxson, J., 2001. Lithospheric buckling of the Laramide foreland during Late Cretaceous and Paleogene, western United States. Rocky Mountain Geology, 36, 13-35.

Underwood, J. R., 1962. Geology of Eagle Mountains and vicinity, Trans - Pecos, Texas. Ph.D thesis, University of Texas.

Uphoff, T. L., 1978. Subsurface stratigraphy and structure of the Mesilla and Hueco Bolsons, El Paso region, Texas and New Mexico. Master's thesis, University of Texas at El Paso.

Woodward, L. A., Anderson, O. J., Lucas, S. G., 1997. Tectonics of Four Corners region of the Colorado Plateau. New Mexico Geological Society Guidebook, 48, 57-64.
Wu, K., 2002. Structural geology and tectonics of the western boundary fault zone of the Franklin Mountains, west Texas. Master's thesis, University of Texas at El Paso.

Zeller, R. A. Jr., 1970. Geology of the Little Hatchet Mountains, Hildalgo, and Grant Counties, New Mexico. New Mexico Bureau of Mines and Mineral Resources Bulletin 96.

Manuscript received: September 14, 2007

Corrected manuscript received: December 6, 2007

Manuscript accepted: December 14, 2007 